\title{
Desirable and Failed Citizen-Subjects
}

The print advertisement in figure 7 , from 1962, features the newly launched national airline, the Pakistan International Airlines (PIA). It signifies the early efforts of the state of Pakistan to modernize and develop, while enlisting its citizens, both men and women, to participate in the nation-building project. The ad boasts the airline's competent staff-pilots and hostesses-but in the process naturalizes women's caregiving roles. While PIA's pilots have received specialized training, its hostesses are simply extending the caregiving services that they have been providing within the patriarchal home for centuries to now the aviation industry. This formulation also serves another purpose: it calls on women to join the aviation industry without seriously disrupting established norms of femininity.

Upon its founding, Pakistan faced myriad challenges from territorial disputes with India and limited economic and administrative resources to a weak democratic structure. Millions of refugees from India had to be rehabilitated, which put intense pressure on the government. The country inherited meager educational and industrial institutions and, hence, immediately launched into building these resources in order to become competitive. Discussions about modernization, linked with technological and scientific advancement, as well as questions about the role of Islam in the new nation, consumed the emerging bureaucracy, state leaders, and newly created citizens. The moment also called for a clear articulation of an ideal Pakistani citizen-subject. Therefore, we find extensive discussion on the topic, which includes not only political discourses and visualities but also attempts by the citizens themselves to define what it means to be a "Pakistani." The figure of the educated female citizen-subject emerges as a meaningful discursive space to map out the different tensions, hopes, and desires that circulated during this moment. 

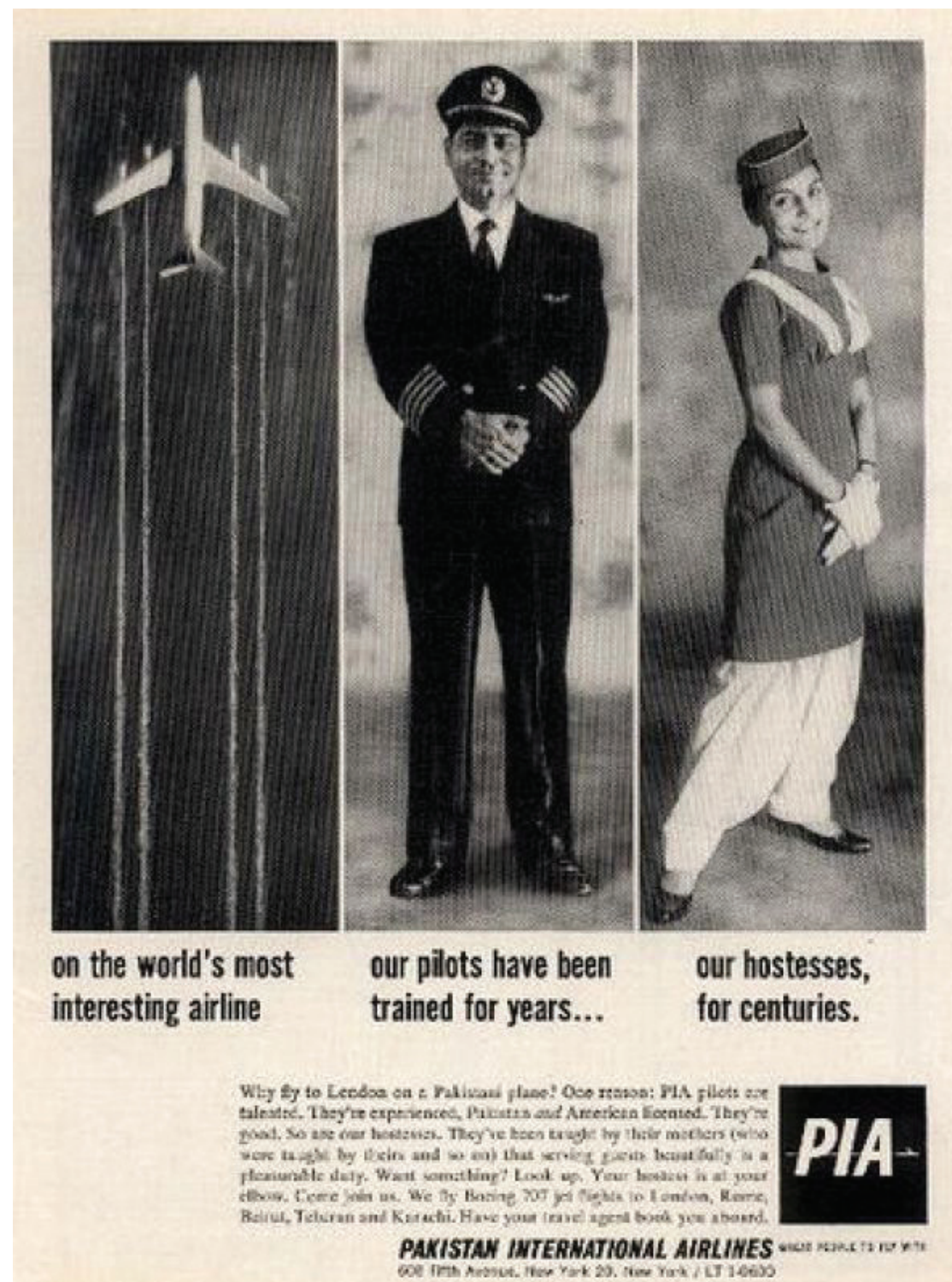

FIGURE 7. PIA advertisement, 1962: "On the world's most interesting airline, our pilots have been trained for years ... our hostesses, for centuries." 
Specifically, in this chapter, I examine the articulations of educated female subjects during the early decades after the political establishment of Pakistan (roughly 1947-67). I review education policy documents published by the government of Pakistan; speeches by politicians; Ismat issues published between 1948 and 1963; Tehzib-e-Niswan issues published in 1948 and $1949 ;{ }^{2}$ an academic study entitled The Educated Pakistani Girl, written by Asaf Hussain and published in 1963; as well as archival photographs. The sources centered in this chapter focus primarily on West Pakistan (today's Pakistan) and were written in the Urdu or English languages. ${ }^{3}$

The ideal educated girl of this period emerges at the nexus of discourses on nation building, modernization, and religion. Education was meant to shape girls into ideal citizen-subjects-an articulation that was gendered. Women and men were expected to perform different duties to advance the state's agenda of development and modernization. Women were idealized primarily as mothers of future citizens or as daughter-workers (like the hostesses in figure 7). In addition, particular kinds of educated female subjects were deemed to be undesirable for the emerging nation, including girls who were enamored by the West and its cultures. Thus, women and girls were cast as either modern or as failed, with the state participating in the production of these definitions through its institutional policies as well as discursive support for particular representations of femininity.

\section{A NATION-IN-THE-MAKING}

British colonizers had tried to make sense of the diversity in India by categorizing its population along religious lines through practices such as the census and cartography. ${ }^{4}$ These categorizations, over time, were taken up by Indians themselves, who moved away from their syncretic Hindu-Muslim (Hindustani) cultural history and language, and toward distinct nationalist groups, calling for separate homelands. ${ }^{5}$ Upon the conclusion of the First World War, for instance, a pan-Islamist movement, the Khilafat Movement, called on the British to protect the caliphate in Turkey and united Indian Muslims to rally behind this cause. Divisions along religious lines were further exacerbated by the intransigence of the Indian National Congress to award constitutional protections to Muslims, as well as the steady conflation of "India" with "Hindu."' By the 1930s, the Muslim League emerged as the political party that represented the interests of all Muslims. It capitalized on Congress's refusals to admit religious distinctions and proposed a separate homeland for Muslims. Even though the leadership of the Muslim League was composed of liberals such as Muhammad Ali Jinnah and Liaquat Ali Khan, the party drew on religion to create a broad alliance across different factions of Muslims. It was during the 1940 session of the All India Muslim League that the "Lahore Resolution" first articulated the political demand for the formation of autonomous states where Muslims were in a majority. The Indian National Congress rejected the plan and clashes between the Congress and the Muslim League continued until the establishment of Pakistan in 1947. 
Pakistan, which comprised of Muslim-majority states and parts of Bengal and Punjab (divided along communal lines), was imagined as the land where ordinary Muslims would live prosperously and have economic opportunity. The official proposal for Pakistan, however, remained distinctly clear of religious ideology. After all, Muhammad Ali Jinnah, the president of the Muslim League, was a secularist and did not intend to mix religion and politics. When the Muslim religious scholars or ulama tried to insert religious ideology (specifically the role of Islamic law or sharia) in the proposals for Pakistan, Jinnah remained firm on his stance, stating: "Whose Shariah? Hanafis? Hanbalis? Sha'afis? Malikis? Ja'afris? I don't want to get involved. The moment I enter the field, the ulama will take over for they claim to be experts and I certainly don't propose to hand the field over to [them] ... I am aware of their criticism but I don't propose to fall into their trap."

However, soon after the establishment of Pakistan, Jinnah passed away in 1948 and the ulama, who before the partition had sided with the Indian Congress over the Muslim League, now sought to influence the trajectory of the new nation of Pakistan. In this context, questions around how Islam should be taken up by the nation-state became prominent: Is Pakistan an Islamic state or is it a state for Muslims? How should religion be part of the nation's discourse? What is the role of sharia? Furthermore, the early establishment officers drew on religious ideology to mask the ethnic and linguistic diversity of what came to be known as Pakistan. The state, thus, emphasized its common religious identity to bind its diverse population. After Jinnah's death, the prime minister of Pakistan, Liaquat Ali Khan, explicitly solicited support from Islamist elements. The "Objectives Resolution" passed in March 1949 referred to Islam as the "religion of the state" and noted that the "principles of democracy, freedom, equality, tolerance and social justice as enunciated by Islam shall be fully observed." The newly emergent nation was drawing on the discourse of Islam to establish its distinct identity. This orientation was also visible in the realm of language policies, personal laws, and-what I am concerned with-educational policies and curricula.

During the 1950s, as the state set out to establish its industries, attend to the needs of its citizens, and neutralize the threat of recolonization by India, it became increasingly authoritarian and centralized. South Asian Studies scholar Saadia Toor observes that the state adopted repressive policies against those who opposed centralization. ${ }^{9}$ Furthermore, this decade was marked by heavy U.S. influence in the country. Since the British had aligned with India, Pakistan sought assistance from the United States (after failing to capitalize on preliminary interest from the Soviet Union), and the United States found it beneficial to engage with Pakistan in order to contain the Soviet influence. ${ }^{10}$ The United States was interested in "using the Karachi-Lahore area of Pakistan as a base for air operations against the USSR and a staging area for forces engaged in the defense or recapture of Middle Eastern oil areas." ${ }^{\prime 11}$ Over the years, Pakistan received economic and military assistance from the United States. In addition, the United States was allowed to set up 
secret intelligence bases and conduct surveillance work. Hence, during the 1950s, Pakistan became "America's most allied ally." ${ }^{12}$

This alliance, however, had destabilizing effects for Pakistan, as the United States encouraged undemocratic and conservative tendencies in the country. It saw religion as a cultural bulwark against communism and, thus, favored a strong central government that allied with particular interpretations of Islam to unify its diverse population. The CIA-backed Pakistan Committee of the Congress for Cultural Freedom, for instance, hosted seminars, talks, and published materials that marked Islam as the potential middle road between capitalism and communism. ${ }^{13}$ Furthermore, instead of encouraging democratic practices in the nation, U.S. officials, drawing on modernization theory, argued that a strong military would be best positioned to lead Pakistan onto the path of modernization, a move that clearly aligned with its own objectivities of curbing the Soviet influence. Hence, in 1958, with American support, the military general Ayub Khan (1958-68) came into power through a coup. Although the ruling party-the Muslim League-was already demonstrating authoritarian tendencies, under Ayub, Pakistan underwent greater centralization. While this period saw the growth of industries, the income gap widened. Ayub's pro-business policies created a welcome environment for tourists, foreign businesses and investments in Pakistan; however, the elite retained the profits. The Kashmir war between Pakistan and India in 1965 proved to be a turning point in the U.S.-Pakistan relationship. The United States did not provide much assistance to Pakistan during the war, instead placing sanctions on the nation while India continued to receive assistance from Moscow. This was viewed as a stab in the back by many authorities in Pakistan. Ayub thus decided that while it was prudent to maintain relations with the United States, it was also critical to establish relations with other major powers, including Muslim nations.

Meanwhile, the state continued to draw on the language of Islam to construct a homogenous population. To ensure that the ulama provided an interpretation of Islam that was inline with the state's modernizing agendas, an advisory Council of Islamic Ideology was proposed in the Constitution of 1962, which together with research undertaken by the Islamic Research Centre provided religious interpretations that were pro-development. Educational institutions, too, were to play a critical role in modernizing the populace through training in the sciences and technology, as well as by forging citizens who exhibited a modern relationship to the state and Islam.

\section{Education for Modernization and Citizenship}

At the time of Pakistan's independence, it is estimated that 85 percent of the population was illiterate, more so in the rural areas. ${ }^{14}$ Education policy in the newly independent state followed some of the broad contours set by the colonial administration-such as maintaining the office of the Ministry of Education and education departments at central and provincial levels-as well as the objective of 
developing key economic sectors of the nation. The British had a functionalist view of education, which was concerned with producing a critical mass of subjects who could run the colonial administrative apparatus and respond to the needs of the colonial economy. The bureaucrats in post-independence Pakistan drew heavily from this approach. Education scholar Ayaz Naseem notes that "the main aim of the educational policy was to create a class of administrators (the civil bureaucracy) and a labor pool that could keep the economy of the new state in line with the demands of the peripheral capitalist system."'15 At the same time, public education was also a key mechanism through which a homogenous citizenry could be produced out of the diverse elements that now formed Pakistan. A review of the early education policy documents as well as speeches by politicians and educators gives us a glimpse into this purpose of education: to produce a Muslim worker-citizen-subject.

During the first National Education Conference, which was held in Karachi from November 27 to December 1, 1947, Muhammad Ali Jinnah emphasized the need to institute an educational system that would make Pakistan competitive with the rest of the world. He noted: "There is no doubt that the future of our State will and must greatly depend upon the type of education we give to our children, and the way in which we bring them up as future citizens of Pakistan. ... We should not forget that we have to compete with the world which is moving very fast in this direction." ${ }^{16}$

From the beginning then, there was a desire for the nation to obtain a competitive edge, which led to an emphasis on advancing technological and scientific knowledges. As Jinnah explained, "There is immediate and urgent need for training our people in scientific and technical education in order to build up our future economic life, and we should see that our people undertake scientific commerce, trade and particularly, well-planned industries." ${ }^{\text {17 }}$ In addition, education was also seen as crucial preparation grounds for creating a democratic citizenry. As Fazl-urRehman, the federal minister of education, noted in 1953: "It goes without saying that the existence of a large bulk of illiterate population constitutes a grave menace to the security and well being of the state. There is now general agreement that in its own interest the state should provide for its boys and girls universal compulsory and free basic education which is the primary requisite training in democracy."18

Earlier in 1948, he had argued that the education system would also transmit universal Islamic values in the populace:

The need for radical reorganisation of the education system to accord with national requirements and aspirations cannot be emphasised too strongly. It also needs no arguing that the education system in Pakistan should be inspired by Islamic ideology emphasising among many of its characteristics those of universal brotherhood, tolerance and social justice... The education system in Pakistan has therefore to embody and reflect those ideals which have been shaped and molded by Islam, [which] far from being a set of dogmas and rituals is a positive philosophy of life and pervades all 
aspects of human activity. It is, therefore, imperative that so fundamental an activity as education should be inspired by the spirit of Islam. ${ }^{19}$

Education, then, from the very outset was described as a critical apparatus of the state that would enable it to compete economically, create a democratic citizenry, and impart the proper spirit of Islam. Therefore, literacy became one of the key sites for investment by the state. During the first National Education Conference it was proposed that universal primary education would be achieved within twenty years. However, it soon became apparent that such a target was improbable due to the lack of teachers. Hence, the National Plan of Educational Development of 1951-57 changed the focus to providing teacher-training institutes. While not much progress was made on this front either, the general rhetoric around education remained linked with labor needs and the progress of the nation. The government of Pakistan's five-year plan for 1955-60, for instance, notes:

Primary education is essential to prepare citizens for the discharge of their democratic and civic responsibilities and to provide them with equal opportunities for economic and cultural advancement. It is essential to the nation as a base for the entire structure of secondary and higher education from which will come leadership in all walks of life and support for technical development in agriculture and industry. ${ }^{20}$

The plan also declared that, "owing to inadequate attention to the scientific and industrial development of the country in the past, a false prestige has been assigned to literary attainments rather than manual dexterity and pride in craftsmanship and technical accomplishment." ${ }^{21}$

A major effort to reorganize the educational system of Pakistan was undertaken during the early years of General Ayub Khan's regime. Ayub's government placed a high priority on education for its capacity to usher in modernity. He established a Commission on National Education, which prepared a report in 1959 that incorporated suggestions made by earlier commissions, conferences, and five-year plans. The Report of the Commission (which was also known as the Sharif Report) proposed curriculum reforms that would enable the development of "basic skills in reading and writing and arithmetic, a liking for working with one's own hands and high sense of patriotism." 22 It also noted that the educational system should produce workers needed for the economy, including the executive class, supervisory personnel, and skilled clerical workers. ${ }^{23}$ The second five-year plan (1960-65) also described the intimate connections across education, national identity, and economic growth-driven development. Thus, education was to produce worker-citizens and launch the nation into industrial modernity. As Ayub Khan said during a Curriculum Committee meeting in 1960, "Of all the reforms we have initiated in the last 20 months . . . the reconstruction of the education system is the one closest and dearest to my heart. No economic planning, social progress, or spiritual enlightenment can make such headway without [a] sound, solid and realistic base of good education." ${ }^{24}$ 
Pakistan's educational agendas were also influenced by foreign elements via aid and technical expertise. Since the introduction of science and technology was assumed to be a key practice through which the nation could modernize, a number of polytechnics were established with foreign technical assistance. ${ }^{25}$ Furthermore, changes in agricultural management were made in consultation with the British government. ${ }^{26} \mathrm{~A}$ number of foreign agencies and academic institutions, including UNESCO, the Harvard Development Advisory Service, ${ }^{27}$ and the Ford Foundation took an active interest in curriculum and teaching in Pakistan. For instance, the U.S. Educational Foundation, one of the Fulbright commissions, was established as early as 1950 in Pakistan. The commission responsible for the 1959 Sharif Report included representatives of western universities such as Cambridge, Indiana, Oklahoma State, Michigan State, Chicago, and Columbia, and foundations such as the Ford Foundation and the Carnegie Institute. ${ }^{28}$ Education scholar Shahid Siddiqui critiques this foreign involvement in the Sharif Report by noting the distinct lack of representation of Pakistanis: "Two out of the four experts engaged in the preparation of Pakistan Education policy were foreigners, i.e. Dr. Herman B. Wells, President of Indiana University, Bloomington, USA, and Dr. John C. Warner, President Carnegie Institute of Technology, Pittsburgh, USA. The two other Pakistani experts, Dr. I.H. Qureshi and Dr. Abus Salam, were also engaged in teaching in foreign university-Dr. Qureshi at Columbia University, New York and Dr. Salam at Imperial College, London." ${ }^{29}$ Siddiqui observes that these relationships were particularly fruitful for foreign universities as they set up research institutes in Pakistan where their faculty could engage in research and teaching. Ford Foundation's ambitions in Pakistan's education sector have also been documented, whereby some officials of the foundation offered to help with the architecture of Islamabad in order to gain favors for longer-term involvement in Pakistan's educational future. ${ }^{30}$ This reliance on foreign monies and expertise has continued to the present, as I elaborate in the next chapter. It is against this background that I analyze the state's calls for girls' education.

While girls' education received attention across all the official education policy plans, in the second five-year plan it was particularly noted that,

of the 4.7 million children presently attending primary schools, only 1.1 million are girls. Clearly, girls must be provided with much greater opportunities for primary education. This will be done both by admitting girls to more of the existing primary schools, and by ensuring that where separate facilities are required a much larger proportion is assigned to schools for girls. ${ }^{31}$

During the same time period-on November 8, 1961-a conference that brought together government officials as well as educators (a detailed overview of which is available in Ismat),32 called for women's education to enhance the workforce, but also noted the lack of teachers and facilities as key hindrances. It seems that, while girls' education was always on the agenda, limited resources prohibited any 


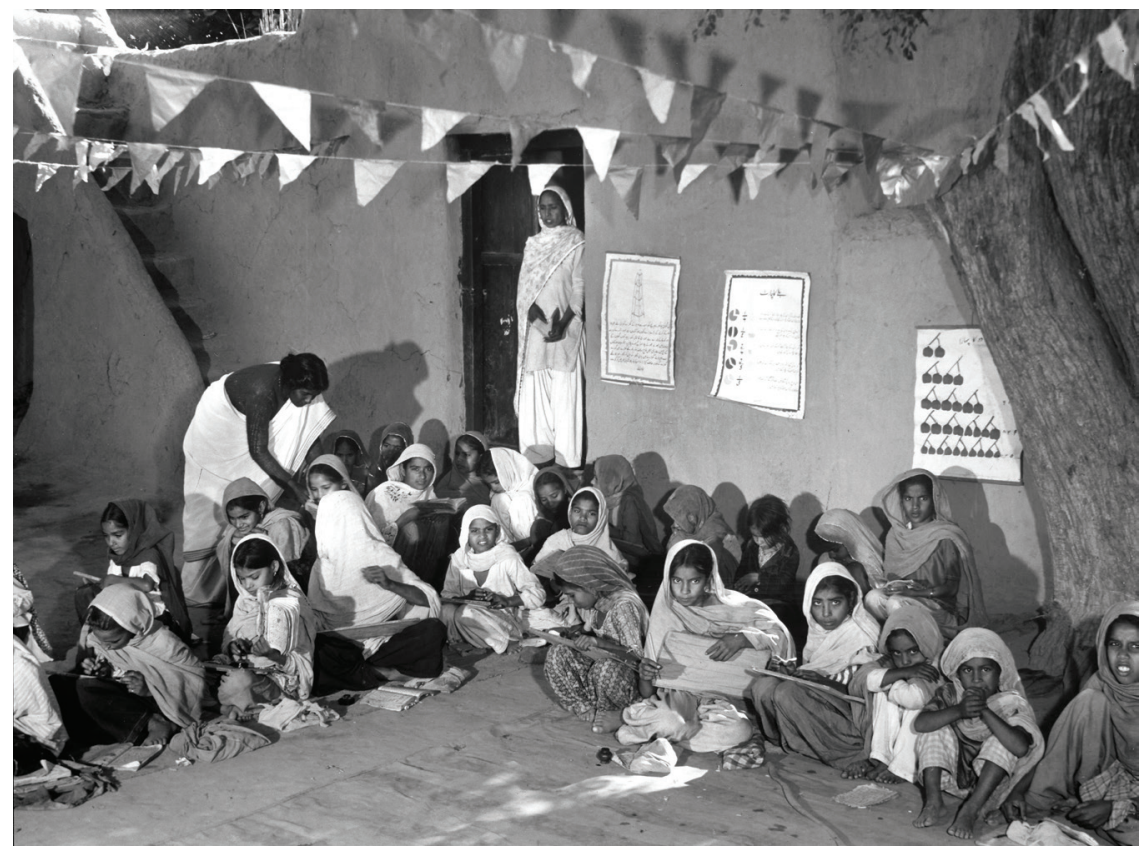

FIGURE 8. Teachers attending to first- through fourth-grade students in a village near Lahore (December 1947). Photo by Margaret Bourke-White / The Life Picture Collection / Getty Images. Reproduced with permission.

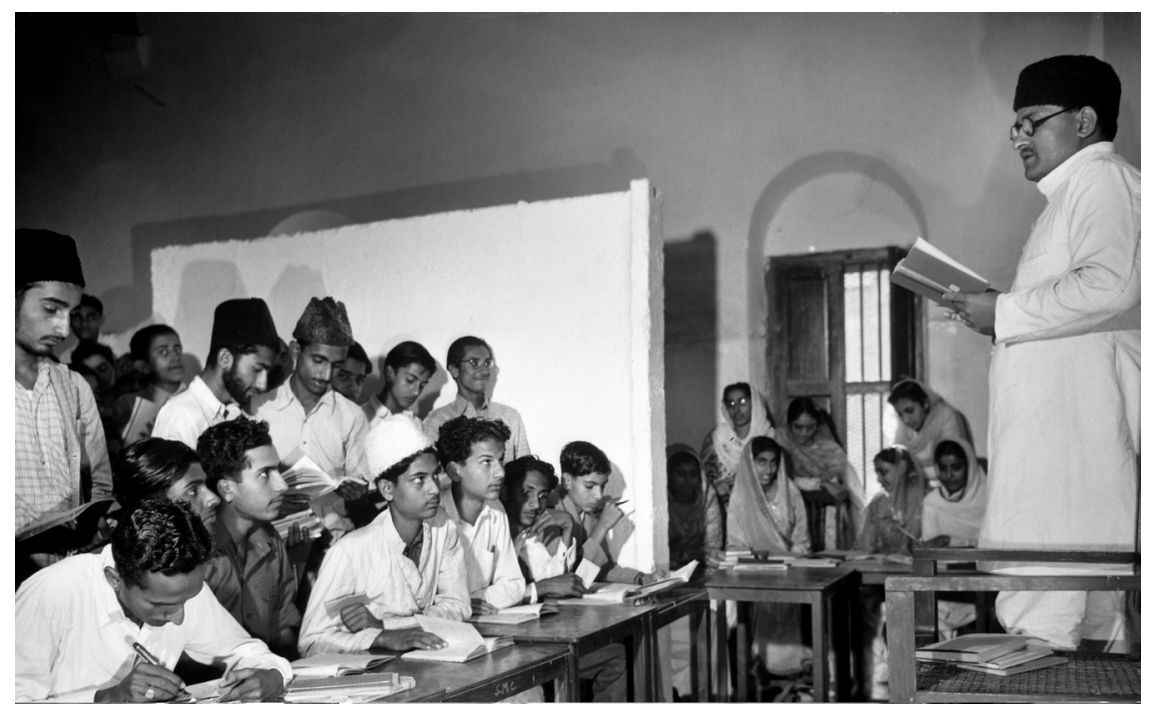

FIGURE 9. A teacher teaching at the Sind Moslem College; female students are seated behind the wall, which functions as purdah (December 1947). Photo by Margaret Bourke-White/ The Life Picture Collection / Getty Images. Reproduced with permission. 
significant progress. Figures 8 and 9 show some of the educational spaces that were operative in the new nation.

More broadly, the Pakistani state institutions saw women primarily through two registers: nation building and development/modernization. In the former case, women's bodies came to be bound intimately with the national project of reproducing Pakistan's citizenry-biologically as well as culturally; and with regard to the latter, middle-class women were seen as an untapped workforce whose productivity was needed for the development and modernization of the new nation. Since low-income women were already active in the informal economy, it was middle-class women who were the focus of the state's attention. The emergence of these subject positions for women coincides with the increasing professionalization of mothering, which in turn was an effect of the popularity of the scientific disciplines of psychology and social work.

\section{DESIRABLE SUBJECTS}

The Sharif Report called for women's education to make women function better within the patriarchal family and contribute to the patriarchal state: "For it is the home-makers of the nation who can best instill the values of order and beauty in the consciousness of the rising generation." ${ }_{33}$ Furthermore, the report identified areas of study and professions deemed appropriate for women, or those that might come "naturally" to them:

elementary homecraft, needlework, tailoring, weaving, cooking and home and childcare. It is suggested that vocational centers for women should teach nursing, teaching, photography, typing, textile printing, commercial cooking, hospital aid, dietetics, nutrition expertise, textile design, supervision of village aid hospitals, supervision of bursary schools, midwifery, child psychology, household management, interior decoration, and for national emergency situations women should learn to become stenographers, typists, clerks, secretarial workers and telecommunication operators. ${ }^{34}$

Such didactic messages from the state also circulated through other channels, such as mass media linked to its industries, particularly the tourism and aviation industries. In addition to the advertisement reproduced in figure 7 earlier in this chapter, here is another one published in the Pakistan Times in 1966 (fig. 10). With the caption "Pakistani girls make good daughters-no wonder they make such good Hostesses," this ad was placed by the recently founded national airline. In the ad, a woman appears to be discharging her traditional role as an adept caregiver. The ad notes, "affection for the young, respect for elders and the desire to be helpful, hospitable and gracious ... make-up every daughter of Pakistan." So, the Pakistani woman makes an ideal airhostess and can be "Pakistan's Ambassador in many countries abroad."

In this vein, it should not be a surprise that Pakistani women were also used as a symbol to bolster tourism, simultaneously alleviating the anxieties of 


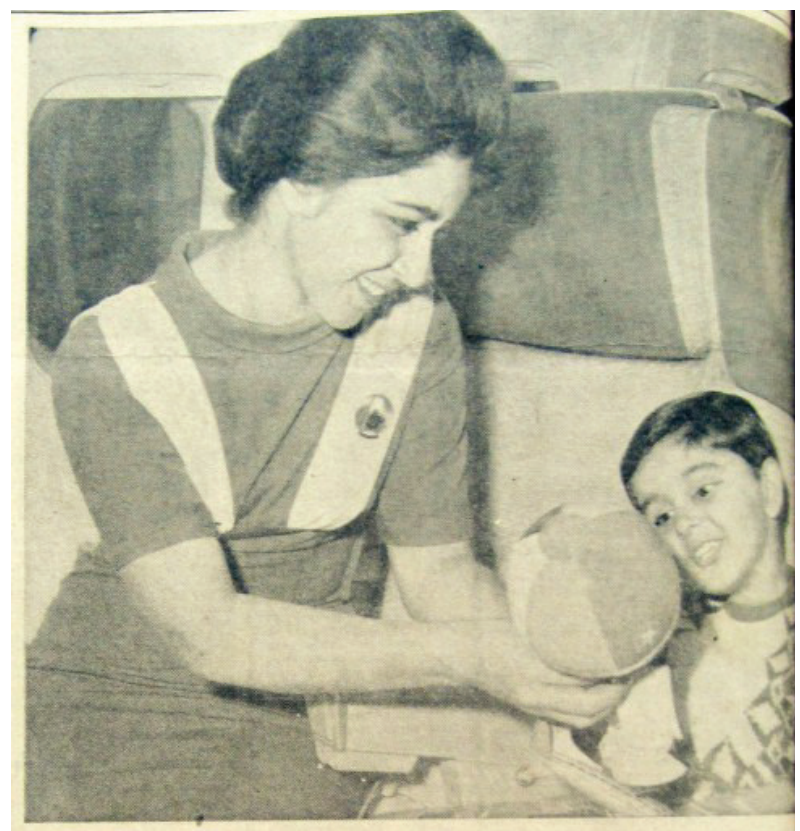

\section{Pakistani girls make good daughters -no wonder they make such good HOSTESS}

Affection for the young, respect for elders and the desire to be helpful, hospitable and gracices. ar

in the make- up of every daughter of Pakistan. has to serve Heads of State and other distinguished persons. Quite often, she is the first cont foreign visitor makes with Pakistan. These great responsibilities carry equally great rewards-you go abroad very often, have Ge
FOREIGN ALLOWANCES to spend, and stay in FIRST CLASS HOTELS. Even your PARE REBATED AIR TICKETS on some routes.

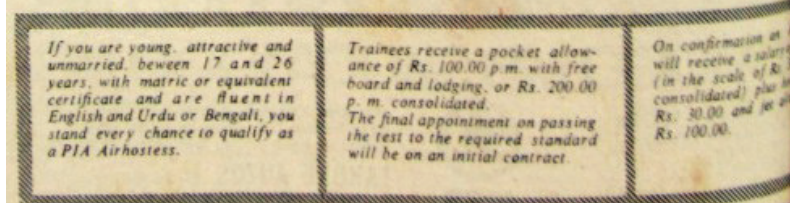
married beveen 17 and 26 yers, will matric or equinglent PIA Airhosiess. Trainees receive a pocket allow. . m. consolidate Te inal appoiniment will be on an initial centraci

\section{Other entitlements include medical facilities, traspont to and duty and free hair styling. \\ Candidates should appear in persen along with their applicall passport size photograph and Certificates-Testimonals in ors the following progrime

\begin{tabular}{|c|c|c|c|}
\hline Station & Date & Time & Place \\
\hline Rawalpindi & $13-9 \cdot 1966$ & 1000 Hrs. & $\begin{array}{l}\text { Office of the District Manager } \\
\text { Flashmen's Hotel. Rawalpindi. }\end{array}$ \\
\hline Lahore & 12.9 .1966 & 1000 Hrs. & $\begin{array}{l}\text { Office of the District Manags. } \\
\text { Shah Din Building. The Mall. Law }\end{array}$ \\
\hline
\end{tabular}

\section{PIA pakistan international airlines}

FIGURE 10. An advertisement for the Pakistan International Airlines published in the Pakistan Times in 1966. Photograph taken by Pippa Virdee, and reproduced with permission. Available at: https://bagichablog.com/2017/o1/30/pia-the-jet-age-andworking-women (accessed January 24, 2018). The newspaper, the Pakistan Times, was closed in 1996. 

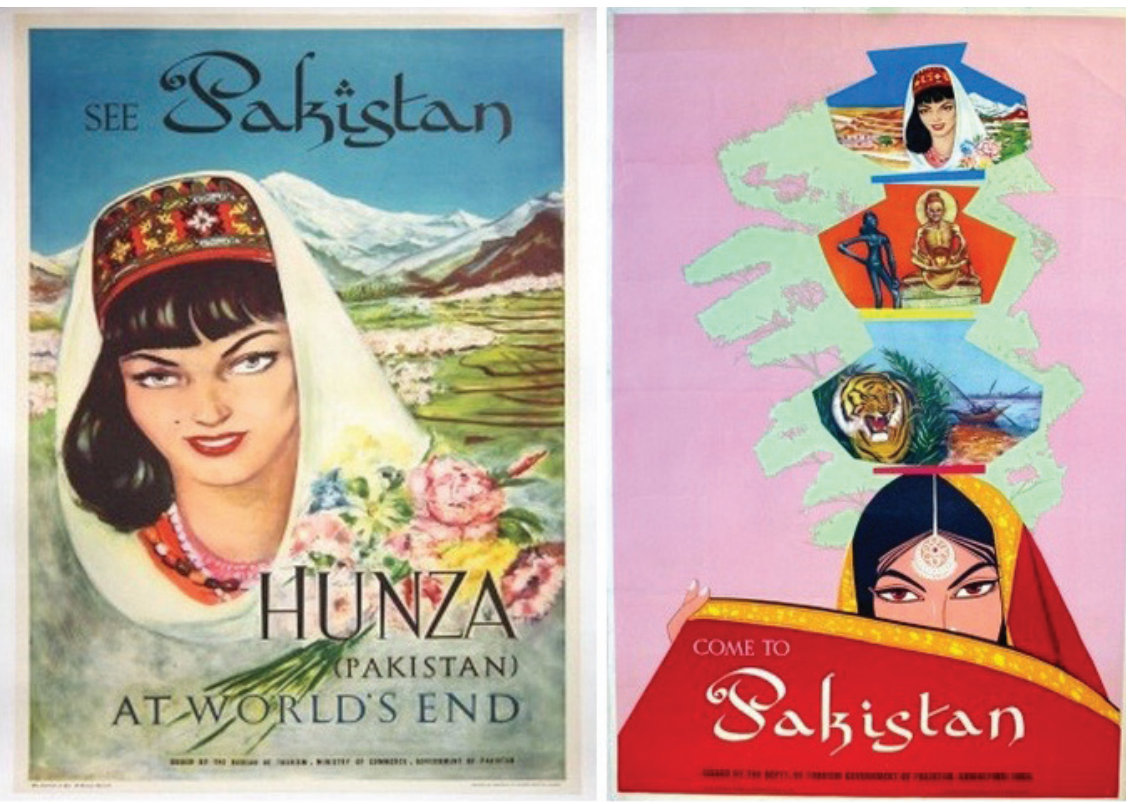

FIGURE 11. Tourism promotion posters featuring women. The poster on the left, "Hunza at World's End," is based on a 1953 National Geographic article and photograph.

predominantly North American and European tourists heading to developing countries for holiday, and feeding into masculinized fantasies. Women represented safety, congeniality, and promised access to beauty and nature. In a poster published by the Ministry of Commerce in the 1960s, with the caption "See Pakistan ... Hunza (Pakistan) at World's End" (fig. 11), we see an image of a fairskinned, blue-eyed woman holding flowers.

This poster was based on a 1953 photograph taken by Franc and Jean Shor for the National Geographic, for their article entitled "At World's End in Hunza: This Strange Shangri-La near the Himalayas Has Few Laws or Taxes and No Army; Bridegrooms Take Mother on the Honeymoon." 35 The photograph depicts "a Hunza woman [as she] knits homespun yarn with needles of modern plastic." Readers are reminded that the National Geographic magazine is notorious for eliciting a colonizing and voyeuristic gaze, as well as for essentialized representations of non-western subjects. ${ }^{36}$ In the poster above, Pakistan's northern areas are transformed into an exotic land, ripe for exploration. ${ }^{37}$ Analyzing the portrayal of brown women in the National Geographic, Moon Charania observes that such images reenact "an old Orientalist fantasy of the mysterious character of the East and of the brown woman, simultaneously repulsive and tantalizing. ... She, as a metaphor for land, becomes available for Western penetration and knowledge."38 
In the posters published by the Ministry of Commerce of Pakistan, too, we observe similar dynamics at play, where women are featured to seduce the (male) traveler. In a 1963 poster published by Pakistan's Department of Tourism (also in fig. 11), women appear alongside exotic animals and archeological finds.

In addition to being enrolled in both representational and manual labor to advance the nation, women were also deemed to have a critical role in the reproduction of future citizens of Pakistan. A speech by Aquila Barlas Saheba, the chairman of the department of sociology at the University of Karachi, at the Literature Association Rally in London hints at this. ${ }^{39}$ In this speech, which is reproduced in a 1948 issue of Ismat, Barlas notes that the project of "building the nation should start with the education and upbringing [talim wa tarbiyat] of women since it is in their laps that future politicians, scientists, poets and soldiers will be raised." Likewise, the then minister of education for Pakistan, in an article entitled "Women's Education," published in 1949 in Tehzib, notes that since the next generation of Pakistanis will be raised by women, women's first responsibility is to be teachers to their children..$^{\circ}$ The new, educated female subject, then, is imagined as a mother-teacher. Readers will recall that similar rationales for preparing the next generation were advanced at the turn of the twentieth century; however, what is different now is that mothering is being linked increasingly to scientific knowledges, which transforms those women who are unable to partake in schooling due to their social class into potentially bad/underperforming mothers.

In order to properly discharge the responsibilities of mothering toward the next generation of Pakistanis, women had to be trained in the sciences. The minister of education for Pakistan in the same article in Tehzib, for instance, calls on girls to obtain an education in the field of psychology, so that they may apply this knowledge to their children. During this time (in 1948), a women's magazine entitled Nafsiyaat (Psychologies) was also launched, which contained articles explaining scientific ways to raise children, with such titles as "Your Child's Future" and "Interpreting Dreams" (1948, no. 1); "Child and Punishment" and "A Child's Psychological Life" (1949, no. 1); "The Effect of Films on Youth" (1949, no. 2); "Educational Psychology" and "Social Psychology" (1950, no. 2). Elsewhere, we find advice for women to prepare healthy domestic environments for children that draw on the latest knowledge of healthcare and commercial products. Consider the following advertisements in Ismat. In figure 12, mothers are advised to prepare food in Dalda oil in order to improve their children's health. The ad begins with a conversation between a mother and a doctor hovering over a sick child. The doctor says, "To keep children healthy, it is important to feed them food cooked in pure oil." The mother is then shown inquiring from a shopkeeper about such a product, who advises her to use Dalda. In the next three frames we learn that her family-composed of the son and husband-are enjoying their meals cooked with Dalda, with the child asking for seconds and the father commenting on how tasty the food is. In larger font we learn that "Dalda provides strength and is pure oil." Significantly, the ad also notes that 


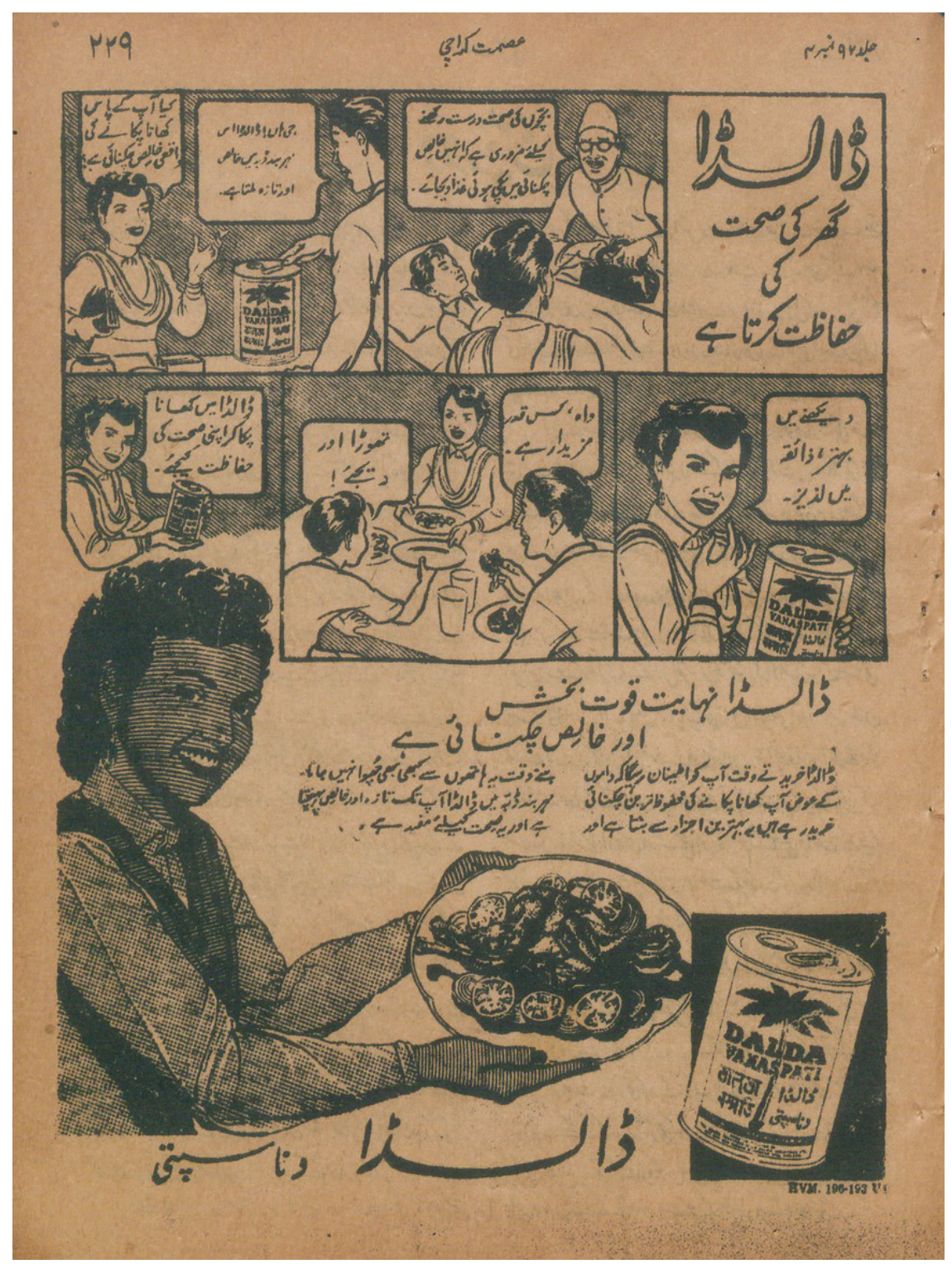

FIGURE 12. An advertisement for Dalda oil. Ismat 92, no. 4 (1954): 56.

during the production process, "it is never touched by hands" and hence arrives in a sealed package "fresh and pure and therefore favorable for health."

Figure 13 cautions pregnant women against germs that they may contract during their delivery. This advertisement for Dettol, an antibacterial product, features 
$r<\Delta$

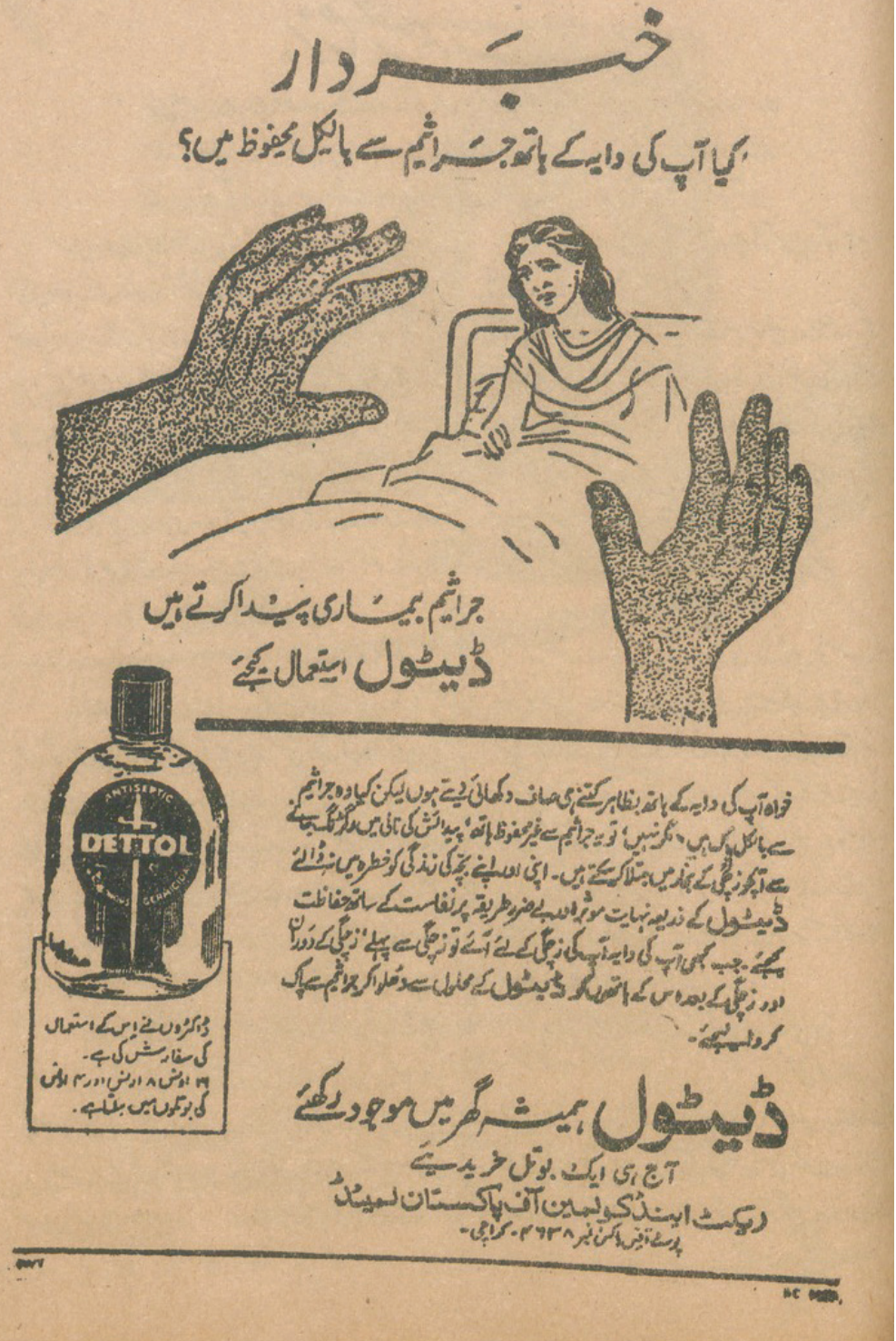

FIGURE 13. An advertisement for Dettol. Ismat 106, no. 5 (1961): 54. 
a pregnant woman who appears to be threatened by the dirty hands of the midwife. The ad opens with "Beware-are your midwife's hands safe from germs?" The ad calls on women to ensure that before, during, and after the delivery, midwives wash their hands with Dettol: "Don't put your own and your child's life in danger."

And, in figure 14, a substitute for mother's milk is introduced. The ad begins with complimenting the child featured in the ad as "cute as well as healthy", and goes on to explain that this is the result of "a mother's love, her nursing, and Ostermilk's attributes." The ad details the several ways in which this milk "is an excellent substitute for a mother's milk." It contains iron to produce enough blood in children, and vitamin D to strength children's bones and teeth. Indeed, "wise mothers raise their children on Ostermilk."

All of these advertisements discursively produce the figure of the educated mother as one who is concerned about the health of her children and draws on modern, scientific knowledge to design safe environments for them. To do so, however, she must also become a discerning consumer. After all, these ads promote particular consumer products. In their study of modern girlhood across the world, Weinbaum and others observe that commodities were intricately linked to the expression of modern femininity. Particular commodities were marked as appropriate for the consumption of the "modern girl." These often included products that enabled them to fulfill their duties either in relation to the family (buying childcare and home-improvement products) or the state (partaking in savings). This insight finds resonance with Satish Deshpande's work in the context of India as well..$^{4}$ Deshpande notes that mid-twentieth-century constructs of citizenship in India were linked to patterns of consumption and production. Members of the elite and modernizing middle classes emerged as the vanguard of the new nation because their consumption aligned with modern domesticity and the productivist paradigm of citizenship. By consuming the right kinds of products, the Pakistani woman, too, was to relate to the nation and the family in ways that promoted their development; in the process, she expressed her modern, class-based identity.

The national discourse that sought to transform women into workers and consumers was primarily aimed at middle-class women who had the financial means to acquire an education and other commodities in the first place. Most Pakistanis lived in extreme poverty in rural areas and were illiterate. The professionalizing discourse that produced the "working daughter of the nation" or the "scientifically inclined mother" was not aimed at them. Poor and peasant women were often already engaged in the informal economy, and lacked both the monetary and cultural resources necessary for accessing emerging consumer products.

For-profit corporations, on the other hand, aspired to transform all kinds of women into consumers. Consider the following print advertisement of a private bank, which features a woman in burka (fig. 15). Even as it positions the burkaclad woman in the time-space of the past by constructing her in opposition to the 


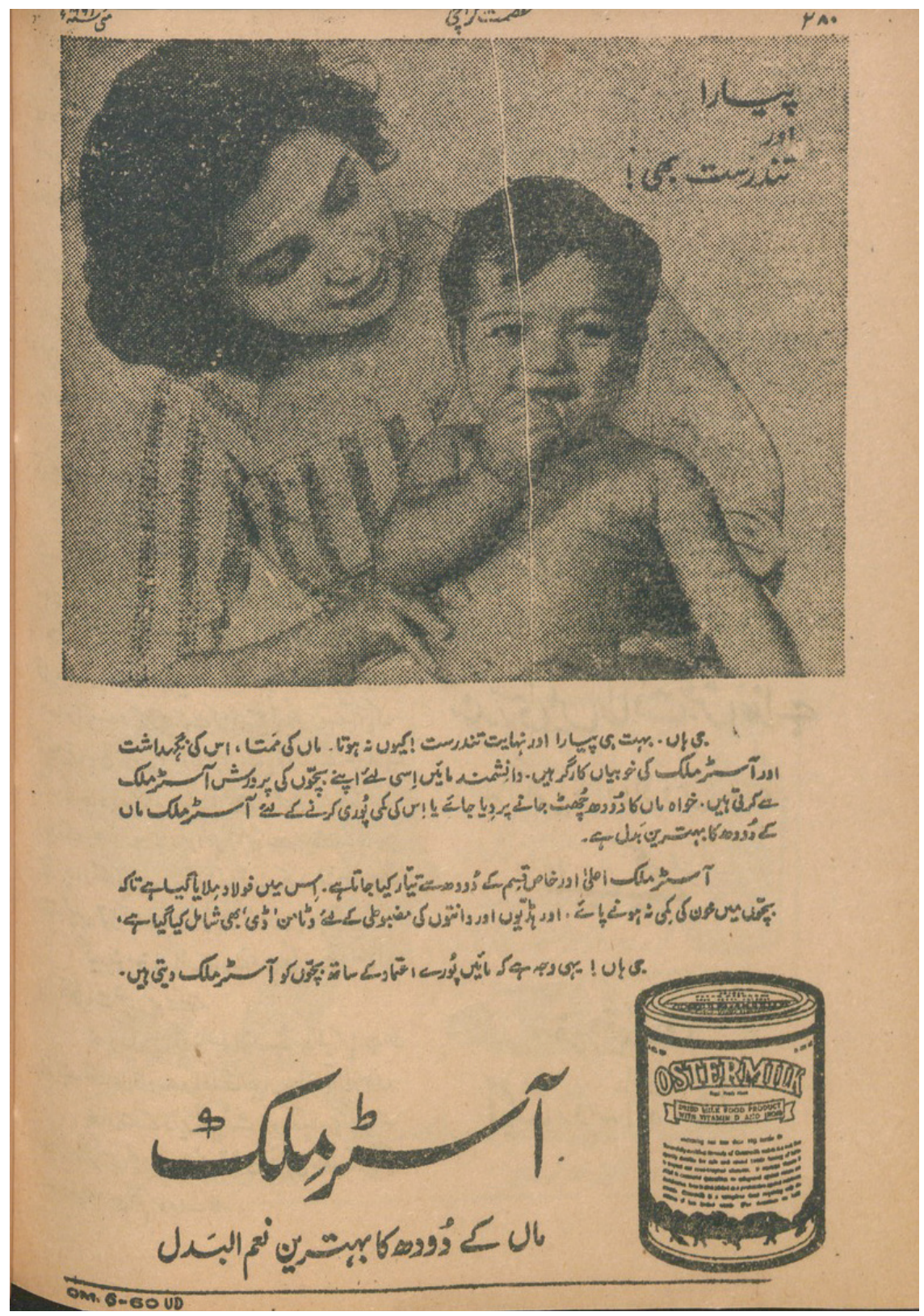

FIGURE 14. An advertisement for Ostermilk. Ismat 106, no. 5 (1961): 59. 


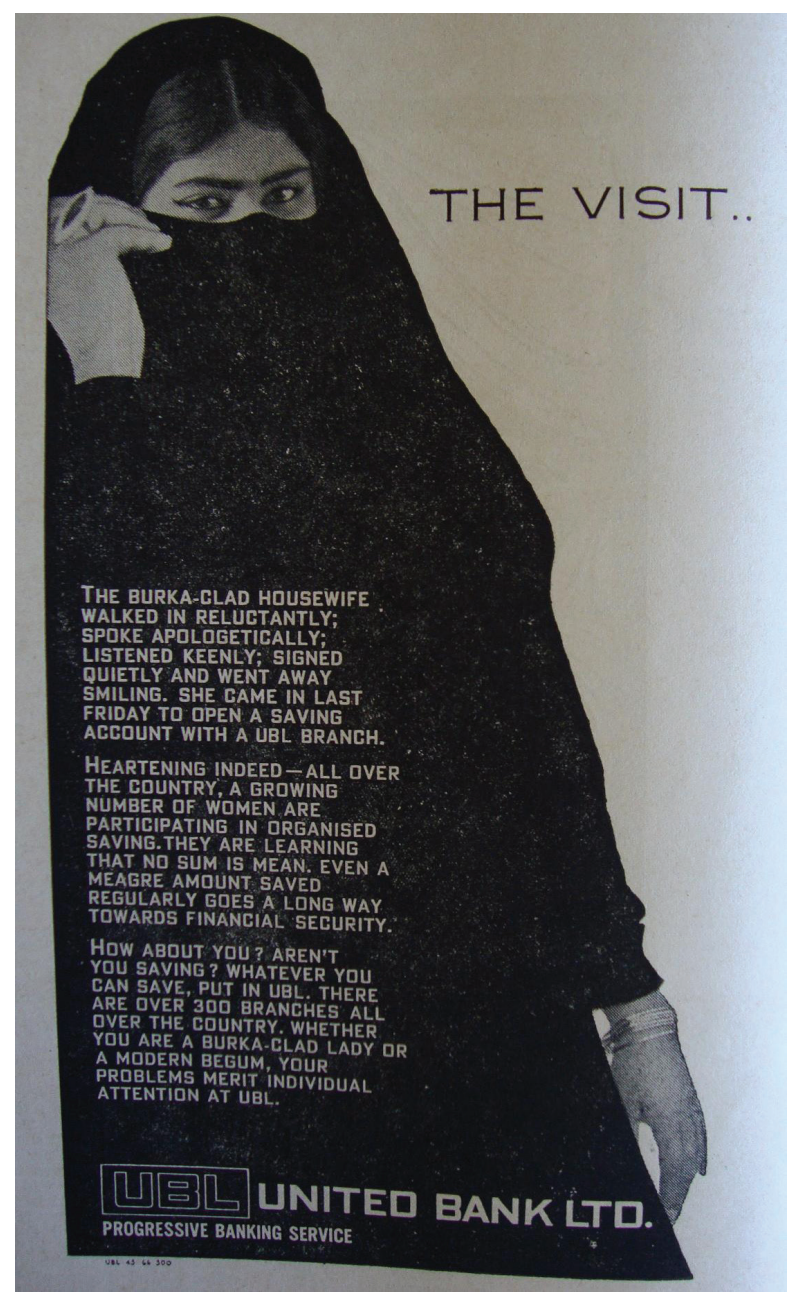

FIGURE 15. An advertisement for the United Bank Limited, which appeared in She magazine, Pakistan, on February 15, 1967. Photograph taken by Liam Kelley. Reproduced with permission.

"modern begum," it sees her as potentially adding value to the nation as a consumer and, hence, is willing to overlook her "nonmodern" expressions of piety. Burkaclad or not, women are called on to transform themselves into consumer-citizens by participating in "organized savings," a critical need for the emerging nation.

Insights from women's periodicals further clarify the class dimension of the discourse on women's education and their role in nation building via waged work. While the state viewed women's labor as critical for national progress and drew on 
the language of "duty" and "responsibility," women from low-income backgrounds often saw such work as a "necessity" in the precarious postindependence environment and even resented it. Bilquis Ahmed Shafiq, writing for Ismat in 1949, for instance, notes that after independence she feels that women have to take on more burdens to improve the welfare of their families. ${ }^{42}$ Similarly, Shaista Suharwardy, in her article "What Is Woman's Work?" in Ismat in 1954, observes that while recent essays in the magazine discuss women's responsibilities to contribute to the family's income, they fail to highlight the difficulties of such work. ${ }^{43}$ She observes that the debate seems to suggest that it is women's choice to work outside the home; whereas, in reality, dire circumstances have compelled women to do so. The author cites the example of many families who, after migrating from India to Pakistan, have had to rely on women's employment in order to make ends meet. In some cases, men are not able to get jobs, have become disabled, or have died. She further notes that while earlier women were taken care of in extended family systems where income and expenses were shared, that is no longer the case. She thus sees work as a "burden" rather than "responsibility" or "duty," terms often used by state institutions. Recognizing these new realities of women, Suharwardy calls on the government to take active measures to ensure that it becomes possible for women to engage in paid work in safe working environments. She calls for modifying school curricula to account for the fact that girls will likely not stay at home and must be educated to work alongside men if need be. In other words, she envisioned schools as transforming women's relationship to paid work. Authors such as Suharwardy highlighted the class dimension that was often erased in national discourses on women's education and work.

Even as the state called on women to take ownership on the domestic front and participate in the economic development of the new nation, it circumscribed their empowerment by constant appeals to men to continue to watch over women. Consider the following advertisements for the Pakistan Savings Certificate scheme published in Ismat.

The first advertisement (fig. 16), published in 1954, is entitled "Danai" (Wisdom) and uses second-person pronouns to address the father:

Wisdom ... As an intelligent and farseeing father, it is your responsibility to educate your children so that they are prepared for life's hard work. It is important to plan and save for education from the beginning. Savings Certificates are issued for precisely this reason, so that you have the ability to save money. You can save your money by buying these certificate and can earn an interest on them too. By doing so you not only prepare for your children's education but also contribute to the country's material resources, so that more educational institutions can be established in the country ... or else, you know that uneducated people are a burden on their family and the nation. Lack of education is the biggest hindrance. Save money and invest in Pakistan Savings Certificate. 


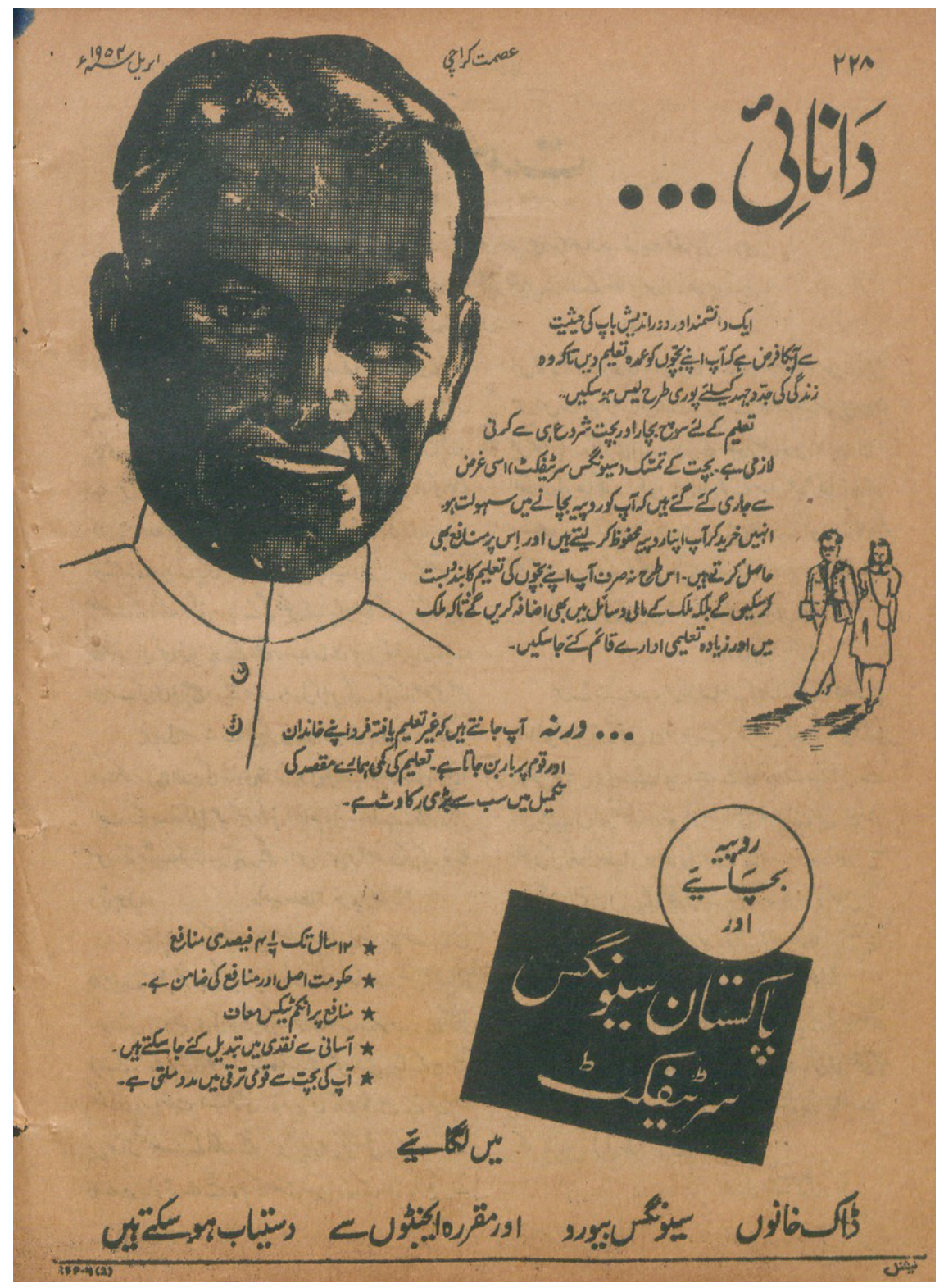

FIGURE 16. An advertisement for Pakistan Savings Certificate scheme. From Ismat 92, no. 4 (1954): 55 . 


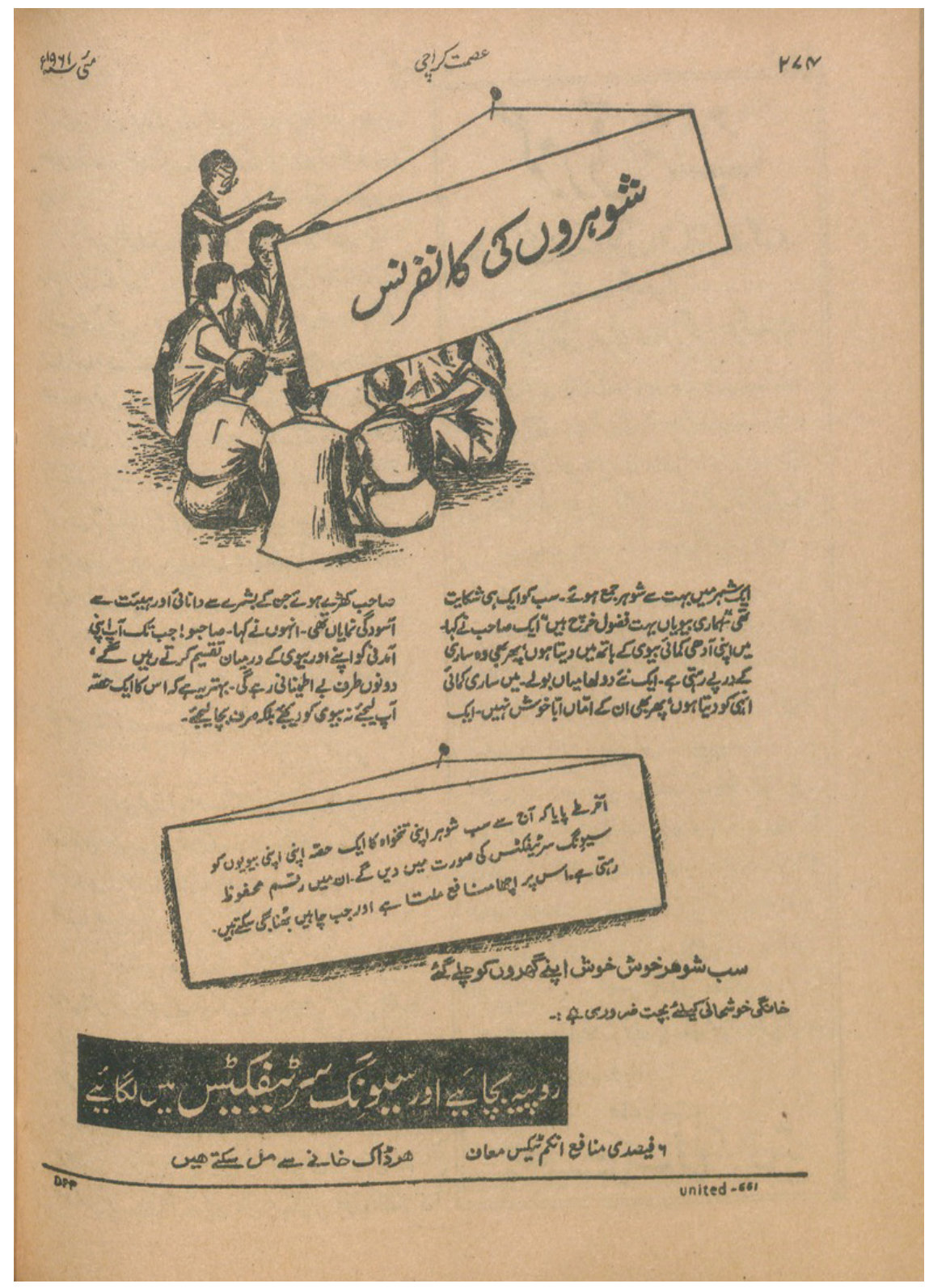

Figure 17. An advertisement for Pakistan Savings Certificate scheme. From Ismat 106, no. 5 (1961): 53 . 
The visuals of this advertisement stand out. In bold letters the word "Wisdom ... " is juxtaposed with an image of a man. A much smaller image of a man and a woman appears on the other side. The reader immediately associates wisdom with men, that men are in charge of the family and so must think and plan for its financial and educational future. What is most peculiar about this advertisement is that it is in a women's magazine but is addressed to men ("as a father . . you"). There is, thus, an implicit logic that even though women will most likely read this magazine, they too, will comply with the normative view that men are wise and guardians of the home. A 1961 advertisement (fig. 17), captioned "Husbands' Conference," draws on a similar logic but is much more explicit in its marking of women as inferior:

\begin{abstract}
Many husbands gathered in a city. Everyone had the same complaint: "Our wives are very spendthrift." One man said, "I give half of my income to my wife but even then it is not enough." A newlywed said, "I give all my income to her, even then her parents are not happy." A wise man stood up and said, "Sahebo, until you keep distributing your income between yourself and your wife, both sides will be uncomfortable. It is better to neither keep the money yourself nor give it to your wife but to save it." Finally it was decided that all husbands will give a portion of their income to wives in the form of a Savings Certificate. This way the amount will be protected, it will earn interest, and whenever it is needed, it can be monetized. All husbands returned happily to their homes. For domestic happiness, savings are necessary ...
\end{abstract}

In this advertisement again, while it is signaled that men rely on women to run the household, there is little trust in women's ability to manage the finances. Women are spendthrift and regardless of how much income men earn, it is never enough. Thus, the ad calls on men to take charge by avoiding giving women liquidity. After all, when women don't have the cash, they won't be able to spend! This logic again establishes husbands as thoughtful leaders of their homes, who can guide their families to prosperity in spite of their wives. Women are called on to play a part in familial and national projects, but, given their natural (rather, naturalized) shortcomings, they need to be managed and controlled by both men and the state.

\title{
FAILED SUBJECTS
}

The demarcation of failed subjects was also a crucial aspect of the discursive project of defining successful performances of educated, Pakistani, Muslim subjectivities. Asaf Hussain's book The Educated Pakistani Girl (1963), provides an intimate portrayal of Pakistani girls during the 1950s, and his categorizations of his interview subjects as purdah-nasheen (those who wear the veil), "modern," and "ultramodern" give us insights into this discursive project. The Educated Pakistani Girl is an interpretation of a mixed-method study conducted by the author. Hussain had collected data from a hundred "educated" girls between the ages of eighteen 
and twenty-five; for the purpose of the study, he defines "educated" as having completed the tenth grade or beyond. While Hussain is mostly concerned with girls' views about love, marriage, and sex, what is most interesting to me is the discursive construction of the "educated Pakistani girl." I highlight some findings from the text, as well as girls' own statements, to illustrate how both being too religious and "ultramodern" came to be seen as inappropriate performances of an educated girlhood. In other words, these performances were at odds with the performance of citizenship and religiosity demanded by the new nation of Pakistan.

Hussain categorizes girls along a continuum of backward to progressive, from purdah-nasheen to modern to ultramodern. He has a clear preference for what he sees as the middle ground-the "modern Pakistani girl." He sees the purdahnasheens as "misfit[s] in a developing society" 44 because they partake in what he sees as a regressive practice (the purdah), believe in the superiority of men, and find coeducation to be distracting. He also observes that the pardah-nasheen girls were not able to provide an answer about how they could be helpful to their nation. Likewise, Hussain sees the ultramodern girls or "teddy girls," 45 who were enamored with the West, as also not performing the kind of girlhood conducive for the nation's progress. They were "born and bred in rich, well-to-do, influential families" and represented the "gloss of the educated westernised gentry." ${ }^{46}$ They were "bored with this country" because its people "[are] narrow-minded, customs are outdated, religion is stringent, the country is underdeveloped, the masses are illiterate, and so the question of serving it does not arise." 47 Yet, because they could not visit the West easily, they brought the West to Pakistan through practices such as flirting or casual relations with men, dancing at parties, and being fashion-conscious. ${ }^{48}$ As Hussain notes, "the ultramoderns find it very convenient to copy the Western mode of living, thinking it to be superior, forward and 'cultured." ${ }_{49}$

It is the "modern girl" that Hussain sees as the ideal citizen that the nation can depend on. This girl demands equal rights-as one informant notes, "A country can only develop when both (men and women) have equal rights so that they can participate equally for the improvement of the country"; $5^{\circ}$ and another says, "Women should be treated according to the law of human rights established by the UNO." ${ }^{51}$ They are interested in coeducation so that they can work with men and support their families: "co-education should be encouraged. Keeping boys and girls apart makes them come close and meet secretly and they are misled"; 52 and "co-education is good in a way because it teaches the sexes to walk shoulder to shoulder." 53 They appear to have an approach to gender relations that is in the service of familial and national projects, rather than personal sexual fulfillment and pleasure (like the ultramodern girls) or a rejection of relations with men that would be detrimental to the national developmental project (like the pardah-nasheen).

On citizenship, the author notes that modern Pakistani girls are not like "the living dead ... . the purdah-nasheens, but have a deep-seated urge to help their sisters, their people and their country." ${ }^{54}$ Girls themselves noted: "I would like 
to do something for the uplift of Pakistani women struggling in the quagmire of illiteracy and primeval darkness"; 55 "Give village aid, teach cleanliness and social uplift in order to bring up children properly"; 56 "I am interested in teaching and would like to see our women educated and cultured. It is my wish to help to create good sense and liking for art. There should also be an educational campaign for the masses." ${ }^{77}$ Whereas the ultramodern girl is depicted as belonging to the upper/ elite social classes, the modern girl is middle-class. She is interested in getting an education and working so that she can support her family. She displays proper commitments to the nation - as a transmitter of national culture and a biological reproducer of national subjects. She also monitors her sexual relations, and so, unlike the ultramodern girl, is not considered a threat to the nation. The foregoing constitutes a theorization of "modern" as leaving behind antiquated religious practices (in this case the purdah, gender segregation, etc.) and as being cautious about western social mores (represented by the ultramodern girl's habits). Hussain's articulation of the modern girl, then, is a new invention that is distinctly Pakistani and Muslim.

While these portrayals of girls by Hussain may be reductive, they do point to the discursive conditions within which the "educated Pakistani girl" emerges. They signal how the needs of the new nation, changing social and gender relations, as well as multiple articulations of Islam, created pressures for the articulation of a distinctly modern girlhood that was patriotic and Muslim. During the $1950 \mathrm{~s}$ and 1960s Pakistan portrayed itself as a modern state that welcomed tourists, foreign businesses and investments, and established a large range of industries. During this period Ayub Khan invited several western state leaders to Pakistan to strengthen ties. In 1961, for instance, Queen Elizabeth toured Pakistan and in 1962 the first lady of the United States, Jackie Kennedy, visited as well (figs. 18 and 19). The self-articulation of the nation as "modern" and "progressive" also called for an articulation of a girlhood that, too, could display just the right combination of national pride and modernity. This is the girl that Hussain describes as the "modern girl," upon whom the nation could rely.

The discursive construction of the pardah-nasheen as a failed subject and the "modern girl" as the ideal subject was coproduced in western journalism about Pakistan as well. Consider the following photographs taken by Margaret BourkeWhite and published in the January 5, 1948, issue of the Life magazine. They portray the multiple performances of womanhood at the inception of Pakistan, some of which are marked by the photographer as modern and others as implicitly backward. Figure 20, for instance, portrays a group of women who belong to the National Guard, practicing combat techniques. These women are named by Bourke-White as "modern Pakistan [sic] women," and are juxtaposed with women who observe purdah (fig. 21). Specifically, the caption reads: "Modern Pakistan [sic] women are symptomatic of the progress the new nation is struggling to make. Here, led by Zeenat Haroon, young members of the Sind province Women's 


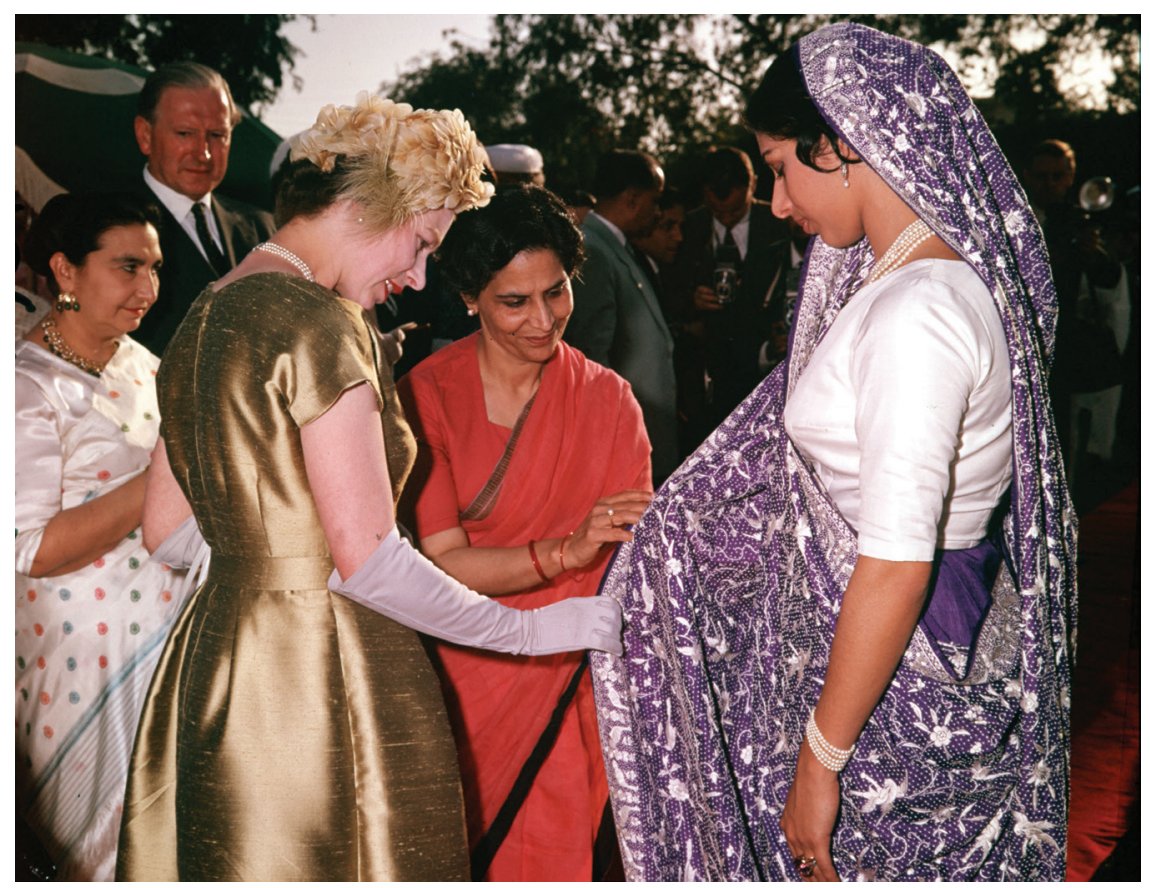

FIGURE 18. British Queen Elizabeth on a royal tour of Pakistan in 1961. Getty Images. Reproduced with permission.

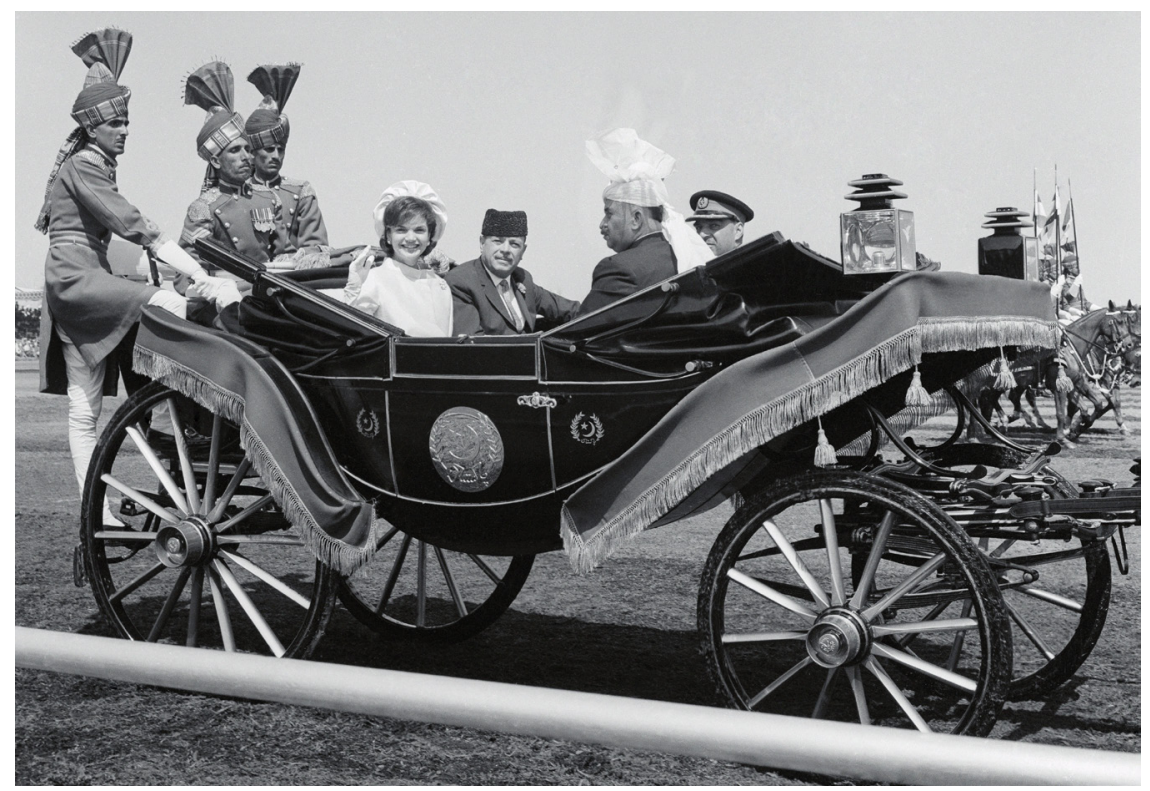

FIGURE 19. First lady of the United States, Jackie Kennedy, visiting Pakistan in 1962. Getty Images. Reproduced with permission. 


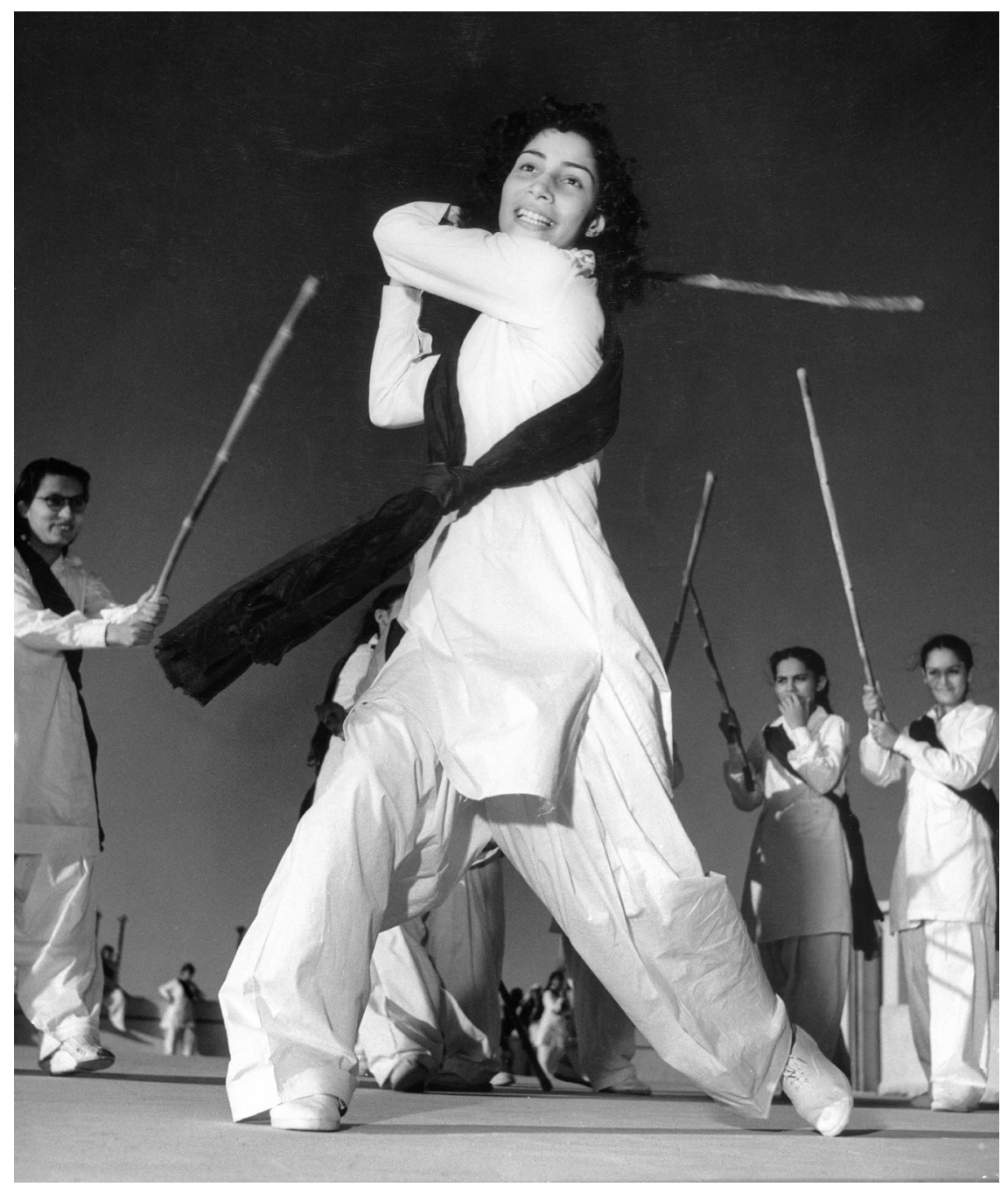

FIGURE 20. Sind Women's Guard, 1947. Photo by Margaret Bourke-White/ The Life Picture Collection/ Getty Images. Reproduced with permission.

National Guard meet to practice the use of the bamboo lathi in self-defense. But most Pakistan women still prefer the old custom, even to the veiled face." ${ }^{38}$

So, even at the inception of Pakistan, some subjects were already marked as inappropriate for the progress of the nation. The binary of modern versus religious hardened over time, as Hussain's book (published in 1963 but researched during the 1950s) reveals. Such binaries, however, were reductive. Certain of the most active women in the project for women's education were pardah-nasheen. Figure 22 


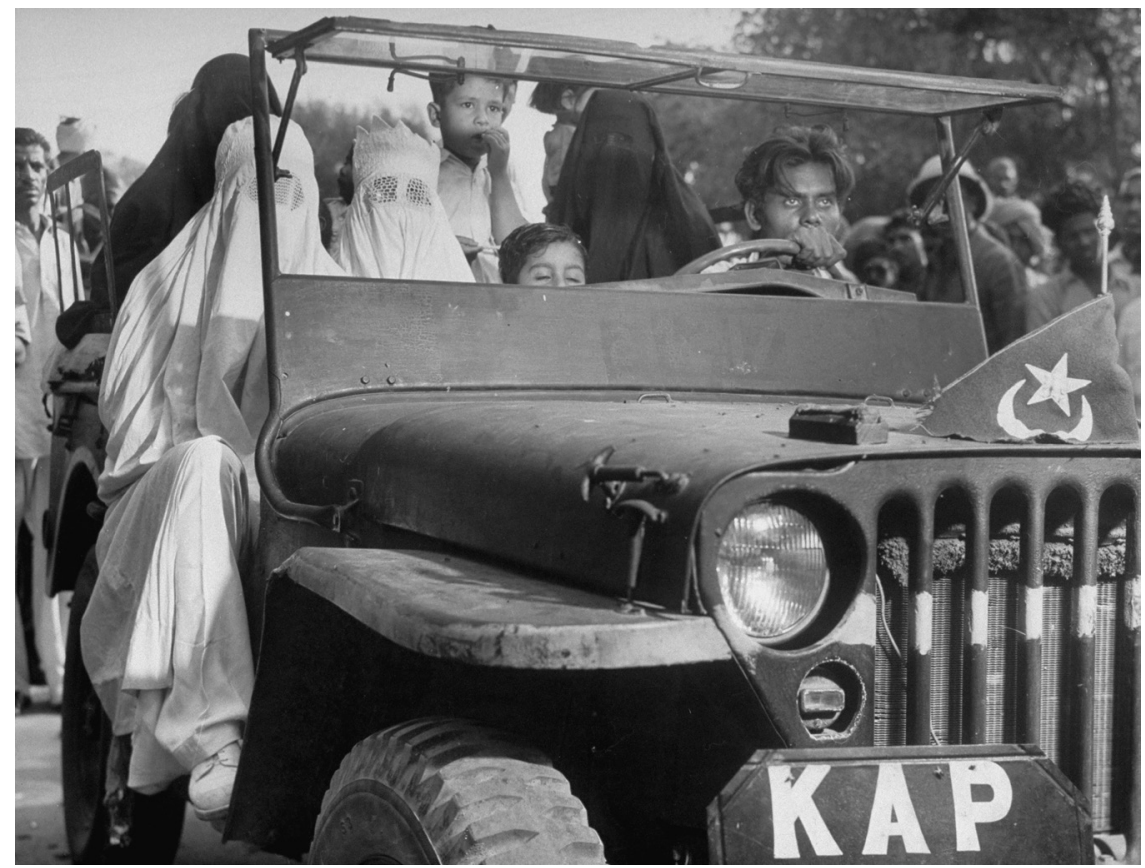

FIGURE 21. Women in purdah going to a park, 1947. Photo by Margaret Bourke-White/ The Life Picture Collection/ Getty Images. Reproduced with permission.

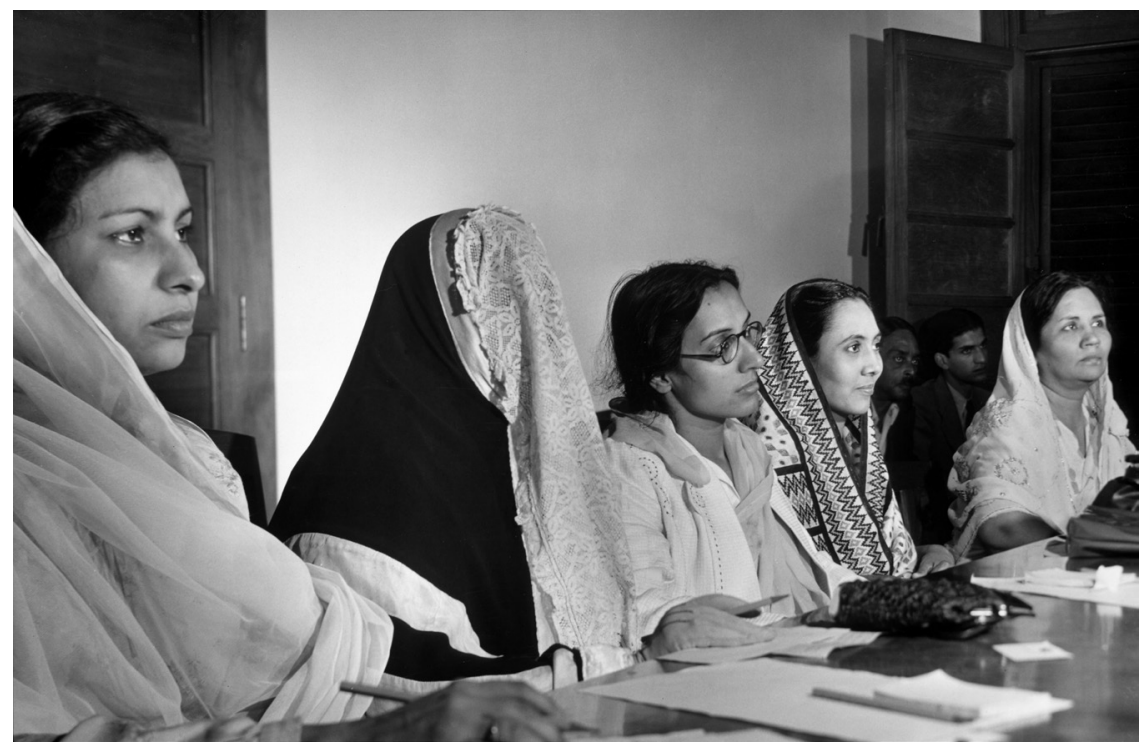

FIGURE 22. November 1947, Women's Educational Conference. Photo by Margaret BourkeWhite/ The Life Picture Collection / Getty Images. Reproduced with permission. 
shows a photograph taken by the same Life journalist during the November 1947 meeting of the Women's Educational Conference. Here, purdah-nasheen Khadeeja Ferozuddin, who was the deputy director of Public Instruction of West Punjab, leads the meeting in which she called for separate medical colleges for men and women. However, the caption in Life of a close up of Khadeeja Ferozuddin reads: "The Lady in the Lace personifies old customs and traditions connected with Pakistan's religion. Although this lady, Khadeeja Feroz Ud-din is deputy director of public instruction for the West Punjab, she opposes co-education. She veils her face and even hides her hands in gloves." ${ }_{59}$ Such narratives leave the "modern girl" as the only site of possibility.

Hussain's survey and narrative illustrate the broad categories linked to girlhood that were in circulation during the early decades after the establishment of Pakistan, as well as the kinds of investments about the nation, Islam, waged work, and family that marked women along the continuum of backward to ultramodern. One key threat to ideal girlhood was represented by English/missionary education.

\section{THE LINGERING THREATS OF COLONIAL EDUCATION}

In women's periodicals as well as policy documents and political speeches, we find scathing critiques of the kinds of subjects that English/missionary education was producing. Early on, the Advisory Board for Education of Pakistan (ABEP), which was established during the first All Pakistan Educational Conference, held in 1947, noted that education should be free from "an over-emphasis on the superiority of modern Western civilization, the glorification of its material achievements and the consequent relegation to a place of inferiority of Eastern cultures," as well as from "the pernicious results of Macaulay's system of education." ${ }^{\circ 0}$ Elsewhere, Fazl-urRehman, the then federal minister of education, concluded that Macaulay's system had led to the "dominance of alien influences in the textbooks, readers and juvenile literature," in such a way that "all traces of Muslim culture were deliberately excluded." ${ }_{11}$ The concern with English education often took the form of anxiety about proselytization in schools, as well as a fear that the next generation would not learn its own language and culture. The Committee of the Punjab Education Department, for instance, contemplated changing the medium of instruction from English to Urdu since the English medium of instruction had "caused considerable mental strain." ${ }^{62}$ Likewise, in June 1948, the Interuniversity Board also decided that English should no longer be the medium of instruction in the universities of West Pakistan and to adopt Urdu within four to five years. ${ }^{63}$ A deeper exploration of women's periodicals explicates these anxieties around missionary education as well as the danger that its students presumably embodied.

Consider the conversation across three issues of Ismat in 1956 and 1957 about convent/missionary schools. We find that colonial legacies in education were seen 
as undesirable for the new nation of Pakistan due to their (real and imagined) corrupting effects on the nation's children. In an article entitled "The Convent School," ${ }^{4}$ written by Zubaida Zareen, the author notes that the movement for an independent Pakistan rested on claims that Muslims needed a separate homeland to sustain their language, culture, and religion. However, she laments that until now there has not been an agreement about a national language and English continues to have a strong influence through convent schools. She complains that such schools produce students who are enamored with the West and consider themselves superior to the average Pakistani child. She goes on to note that while only rich parents in the past sent their children to convent schools, now even middle-class families are doing so, concluding that "it is an inferiority complex that compels many Pakistani parents to do so." The author argues that such students will neither become English nor remain Pakistani; rather, they will be "neem-angraiz" (pseudo-English). She also criticizes the dress prescribed for girls in convent schools (recall figures 5 and 6 in the last chapter). She asks: "Why are we investing so much on this identity-is that why we created Pakistan?" Zubaida Zareen concludes by explaining that while she is not against learning from other nations, "Pakistan should also have its own distinct identity," and she cautions that "such Christian missionary schools will destroy our religion."

Zubaida Zareen's article represents a generational anxiety that consumed the emergent nation's citizens around independence: What will the next generation do with this new nation? What will be the place of Islam in the new nation? How can we preserve our values? There is a clear discomfort with the British legacies, especially educational institutions that prioritized the teaching of English and Christianity, as well as an anxiety around the indecision of the national leaders about declaring Urdu as the national language. As elaborated earlier, the British administration had given Christian missionary societies permission to establish schools across colonial India and the Muslim world more broadly. Such schools were often run by missionaries themselves in the hopes of "saving" native girls and women through conversion to Christianity. Furthermore, many graduates of these schools went on to teach in schools established by the government. ${ }^{65}$ Zubaida Zareen's article elaborates anxieties about the religious conversion of those who attended such schools. We also observe a conflation of Muslim and Pakistani identity in the article: to be a good Pakistani is to be a good Muslim, and since convent schools emphasized Christianity they were viewed as a threat to both religion and the nation. For Zareen this threat materialized in the kinds of attitudes that these schools seemed to engender in its students: convent-school students thought of themselves as superior to other Pakistanis, were enamored with the West, and did not know the Quran; female students did not abide by normative dress codes, signaling a potential for crossing other social boundaries as well.

In response to this article, Mussarat Hamid, in Ismat (1956), argues that while she respects Zareen's views, "it is impossible in the current climate in Pakistan to 
pursue the study of the Urdu language when all higher education materials are provided in English" and when "Pakistan is dependent on the United States and England to advance its educational system." ${ }^{66}$ The author then compares the state of government schools with convent schools, noting that the former often have a low quality of education. In such schools, children often engage in "cursing and bad behavior." So, she questions Zareen's argument about how such schools can teach ethics and culture. While Hamid agrees with Zareen that Muslim children should know religion, she thinks it is the responsibility of their parents (and not of schools) to impart such knowledge. Hamid then directs her attention to the state, critiquing it for a lack of effort to improve the quality of education. In Hamid's article we find a distinction between religious/moral and secular education that will congeal over the next decades in Pakistan, with the former being assigned to the "home" and the latter to the school. While Hamid argues that parents should take over moral instruction, she does not acknowledge the explicit and implicit presence of Christian morality in convent schools, which Zareen points out so painstakingly.

In the 1957 issue of Ismat, we find yet another article on convent schools written by Bushra Sultana Rohi Saheba that engages the two previous articles. ${ }^{67}$ The author observes that while the state of public schools is bad, it does not mean that parents should send children to convent schools. The author provides pragmatic solutions to improve public schooling, such as by increasing teachers' salaries. However, like Zareen, she too worries that if children continue to go to convent schools, over time "Pakistanis will lose their culture, unity, and religion." She writes, "We will no longer remain Muslims. We cannot expect that our children get an education in convent schools and yet have the same kind of respect and understanding of religion that Muslim children have; that is not possible." The author clearly makes a connection between education and subjectivity, noting that an English education will not engender the kinds of values that she deems significant for Muslims. Like Zareen, Sultana Rohi also believes that studying in convent schools results in alienation from society because students begin to think of themselves as superior: "Instead of English, English-like Pakistani leaders are being born." She asks: "Should one sustain this destruction just because children will know how to speak English?" She thus calls for more efforts to improve government schooling.

This set of articles not only highlights the issues surrounding the educational legacy of the British but also the anxieties of an unknown future. Specifically, we observe an effort to delineate a distinctly Pakistani and Muslim subjectivity through an emphasis on national language, public schools, and religious practices, and the simultaneous marking of English and Christianity as threats to this subjectivity. These calls were situated in a wider landscape, where anti-Urdu and antiPakistan efforts were on the rise in neighboring India. For instance, after partition, the Hindu Mahasabha, the Jan Sangh, and the RSS demanded a Hindi-only policy in India. The calls to establish Urdu as the national language of Pakistan were to 
signal Pakistan's distinct culture and religion. This not only resulted in contesting the role of the English language in Pakistan-as the authors of Ismat did-but also the suppression of other dominant languages, particularly Bengali. Consider the words of Jinnah during a speech in Dhaka on March 21, 1948: "Let me make it very clear to you that the state language of Pakistan is going to be Urdu and no other language. Anyone who tries to mislead you is really the enemy of Pakistan. Without one state language, no nation can remain tied up solidly together and function. Look at the history of other countries. Therefore, so far as the state language is concerned, Pakistan's language shall be Urdu." ${ }^{68}$

According to Toor, to recognize the claims of Bengali would mean agreeing to the possible "cultural non-contiguity between the two wings [of Pakistan], which would undercut Pakistan's claims to nationhood"69 and the very idea that Muslims shared the same culture and history. Opposition to convent schools, coed schools, and proposals for the inclusion of Urdu in the curriculum, hence, occupied a central place in the struggle for the meaning of Pakistan and Islam. And, women were a key discursive space for clarifying the negative effects of convent schools.

Consider an article entitled "The Curriculum of Women's Education" by Imam Akbar Abadi published in 1956 in Tehzib. ${ }^{70}$ In this piece, the author laments that the contemporary curriculum of women's education is leading to shamelessness. He notes that while no one should be against women's education, the educated generation's assumptions about progress have transformed women into "Japanese dolls" (a reference to superficiality). He observes that the current curriculum makes women experts in writing afsaneh (short stories), reading and writing in the English language, and developing interests in dancing, but does not engender ethical and intellectual thought. The author argues that for a nation like Pakistan, a different kind of education is needed for women-one that enables them to learn ethics and compassion, independence and self-confidence, love for country and nation, and an understanding of their rights. Abadi, then, sees women primarily as citizens who are to serve the emerging nation through their contributions at home and perhaps also through waged work. Thus, education that does not enable women to perform these tasks appears frivolous to him. He emphasizes that the question is not whether or not women should be educated, but what kind of education should they have and how to discontinue the contemporary (English) education.

Suraiya Pardeen articulates similar anxieties around missionary education's effects on women in her article for Tehzib, "A Woman's Status and Responsibilities in Pakistan," published in 1948..$^{71}$ Pardeen gives the example of her own city of Abbottabad, where, though the majority was composed of Muslims, most schools and colleges had been established by Hindus or Christians. While Pakistan inherited the state-run primary and secondary educational system, this infrastructure was concentrated in urban areas and was predominantly run by Hindus who later 
left for India. In Karachi, out of the total thirty-five secondary schools, only half a dozen were managed by Muslims. ${ }^{72}$ In this context, Pardeen laments, "Muslims had no choice but to send their daughters to study there." However, she goes on to criticize English schooling, saying that it is no longer sufficient to memorize a couple of English verses and call oneself talim-yafta (educated); the study of the Quran should be included in the curriculum so that people can become "real Muslims." Likewise, Rashid Siddiqui published an article in Tehzib in 1948 entitled “Today's Muslim Woman," 73 in which he argues that today's parhi likhi (educated) women have been directed away from simplicity and toward fashion, and have become western-oriented: "over time western superficiality took over eastern sharafat."

Similarly, Fatima Begum Saheba, in her Ismat article "Our Girls' Education and Upbringing"74 published in 1957, emphasizes that while women play a paramount role in the building and progress of the nation, they can also be the cause of its downfall. She laments that little attention is being paid to girls' education and observes that girls in schools and colleges do not wear appropriate clothes ("they wear tight clothes"), have short hair, laugh loudly, and desire to become like Christian women from Europe. They want to do well in men's sports, hate the Persian language, preferring the acquisition of English and French languages, avoid religious education, look down on Islami colleges, and are proud of missionary-school education. She proposes that all of this could have been prevented had girls been given religious education. Instead, girls learn to play the piano and dance because it is assumed that "the more modern, fashionable and forwardlooking a girl is, the better her prospects for getting married into a rich household." To disrupt these beliefs, the author argues that the government should make it mandatory for children to learn the meaning of the Quran. She also proposes that housekeeping should be introduced in school curricula and that, in addition to the English language, Arabic should be made compulsory. She calls on other women to advocate for these curricular changes as well, and concludes with remarks that will continue to haunt the Pakistani educational system for decades: "So what if girls of the nation become lawyers, magistrates, judges, doctors, professors, and clerks? So what if they have B.A., M.A., Ph.D., M.B.B.S., L.L.B.? Only if they become real Muslim mothers will the Islamic Republic benefit."

Across these, and many other articles in the periodicals, ${ }^{75}$ there is an acute sense that while convent education is producing both male and female subjects who do not have the ideal orientation and attitude toward the nation and religion, the stakes are higher when it comes to women since they symbolize familial sharafat and have the responsibility of nurturing the next generation. Suraiya Pardeen's binary of "western superficiality" versus "eastern sharafat" indicates these tensions. To be sharif entailed engaging in the proper practices of Islam and orienting oneself to others and family in ways that would be acceptable within a Muslim 
framework. This framework, however, was not clear or universally agreed upon by any means. There was extensive debate about what an education inspired by Muslim ethics would look like. An interesting set of articles in Ismat in 1948 illuminates this tension. ${ }^{76}$

It is a letter written by Mushtaq Ahmed Zahiri, addressed to Latifa Khanum, that elaborates how education inspired by eastern traditions (including Islam) is distinctly different from western traditions. The letter was a response to Khanum's earlier criticism of Zahiri, a regular contributor to Ismat, for being against women's education and independence (azadi). Since Zahiri often employed the language of religion, Khanum as a rebuttal provided evidence of Muslim women's independence in Turkey, Iran, and Egypt, as well as examples of Muhammad Ali Jinnah and his sister Fatima Jinnah. Zahiri's detailed response to Khanum gives us a glimpse into a kind of rationalization that is surprisingly prevalent in Pakistan today as well. It also lays out some of the sacrifices-especially in terms of sacrificing women's mobility and access to knowledge-that particular segments of society were willing to make to secure what they deemed to be proper education.

Zahiri argues that he does not oppose women's education-he is against the specific kind of education that had become dominant in the aftermath of the British raj. "Everywhere you look," he says, "you will find people who are greedy, only interested in accumulating wealth for themselves, and willing to cheat, lie, and loot others to get ahead." 77 He notes that the people who run Pakistan and Hindustan are educated but they take bribes, are unjust, and take advantage of others. This, he believes, is a clear indication of the results of contemporary forms of education. In contrast, Zahiri argues, haqiqi talim (real education) is one that "makes man human," so that he acts justly and fulfills his responsibilities. A human should not simply be invested in accumulating wealth and fulfilling his greed; he should, instead, fulfill his responsibilities to Allah, his parents, relatives, the poor, and orphans. This kind of education, Zahiri states, is necessary for both men and women. However, he notes that until such an education can be provided, it is prudent to stay away from contemporary forms of education, because if one is "influenced by English education then haqiqi talim loses its effectiveness." In contrast to English education, the author proposes that Asia-i-talim (Asian education) should be pursued because the latter is grounded in religion and ethics. Clearly, Zahiri believes that decidedly different values and morality are advanced by English and Asian education. The latter, in his view, is grounded in different epistemologies, an argument that is now, interestingly, being made by decolonization scholars as well. His proposals, however, do not lay out a plan to revise the current educational system and appear to cut off women's access to prevailing opportunities, a move that was resisted by Khanum, who called him out on it.

The writers in Urdu periodicals were aware that they had to work with the infrastructure of schooling from the colonial period and called on the state to take a more active role in building educational institutions. Thus, many articles focused 
on figuring out ways to modify the educational system in response to ongoing threats. This included contemplating the role of Islam in the educational system (as the Imam Akbar Abadi and Fatima Begum Saheba's articles illustrate) as well as exploring how distinctly Islamic values, morals, and traditions could be transmitted via schools. These public discussions around school knowledges led to many policy changes. The 1959 education policy, for instance, made it compulsory for a course on Islamyat (the study of Islam) to be taught up to the seventh grade (the 1972 policy extended this to tenth grade, and the post-1977 policies made it compulsory for eleventh and twelfth grades as well as professional colleges). The 1959 education policy also made provisions for teaching in Urdu. Over time, a number of public schools were established to meet the needs of the population; however, these schools emulated British models of schooling and did not resolve questions around religious/moral instruction.

Over the subsequent decades, a class-differentiated educational system emerged in Pakistan, with the rich sending their children to grammar/convent/ missionary/private schools, while the poor did not have access to schools and the upwardly mobile middle classes strove to improve the public educational system and/or establish low-tuition private schools. The debate about private versus public schooling continued to take center stage. The 1966 Commission Report, for instance, outlined key difficulties with the private sector, and in 1972 the government nationalized all private schools except religious education institutions. $^{78}$ The 1979 policy, however, reversed this nationalization, followed by an encouragement of the private sector from 1992 onward. ${ }^{79}$ This led to a rise in the number of private schools, which were again in the 2009 national policy deemed to be at odds with the public sector. ${ }^{80}$ The government continued to invest in school infrastructure and saw an increase in enrollment rates. Net enrollment in primary school increased over time to 79 percent for males and 65 percent for females, and in secondary school to 40 percent for males and 29 percent for females (data from 2008-12). ${ }^{81}$ Schools became the dominant site for Pakistanis to acquire an education. However, concerns around appropriate knowledges continued to be aired. Curriculum reforms also put pressure on madrasas to clearly define their curriculum as distinct from the government's, and in the post9/11 context madrasas were stigmatized as international pressure on Pakistan increased..$^{82}$ Meanwhile, private providers of education grew rapidly, especially in the rural areas where they exploited the saturated market of low-waged teachers to gain maximum profit. ${ }^{83}$

\section{IN THE SERVICE OF THE FAMILY AND THE NATION}

Whereas in the last chapter I showed that women's education was assumed to transform them into subjects whose actions signaled familial respectability and social status, in the current chapter, we have observed that anxieties about the role of 
Islam in the new nation, concerns about Christian proselytizing, and the national imperative to modernize and develop, created the context within which women's education took on new meanings. Women were not only to represent familial respectability, but now also to partake in the cultural and economic reproduction of the nation. The different discourses on women's education with their attendant knowledges presented in this chapter point to the multiple ideals of desired and undesired educated subjects that circulated in postindependence Pakistan. Both the pardah-nasheen and the "ultramodern/teddy girls" represented failed subject positions because they had not been able to form the ideal relationship to religion and the nation. In the case of the latter, it was the knowledges imparted at missionary/convent schools that were seen as wanting, and for the former it was the staunch disengagement with modern institutions (such as coeducational schools) that was marked as regressive. The ideal educated subject was one who engaged with the institution of religion in ways that did not hinder the modernizing project of the Pakistani state, ready to contribute to the development and economic growth of Pakistan and prepare future citizens. In other words, ideal girls were future "scientifically inclined mothers" or "daughter-workers." These subjects were brought into being through a range of practices, which included not only formal state policies that expanded school infrastructure and opened up specific industries to women, but also the articulation of women as natural caregivers and daughters of the nation through populational reasoning and curriculum.

Feminist historians have illustrated that in moments of political crises new roles become available/accepted for women. This also happened in the context of Pakistan. The nation enlisted women for its modernization project, making available to them new domains of economic activity. However, women's articulation as mothers and daughters prevented any major moves toward women's independence from the patriarchal family and state. Laura Bier traces similar shifts in women's experiences in the context of Nasser's socialist Egypt (1956-70). ${ }^{84}$ She argues that while the state made available new work opportunities for women, it did not address the gender inequalities embedded in the Muslim Personal Status Law. There was, thus, a serious contradiction in the state drawing on feminism to mobilize women to participate in its development project without meaningfully disrupting the persistence of male control in the sphere of the family. These observations ring true in the context of Pakistan as well.

The Pakistani state acceded to conservative elements, sometimes even enshrining women's inequality in law. For instance, during the 1950 s and 1960s, when the Pakistani state sought to reform Muslim laws that governed the family sphere, it acquiesced to the ulama's demands that often strengthened men's control over women. The ulama dissented against the recommendations presented by the first commission set up to review Muslim family laws in $1955,{ }^{85}$ which led to a revision that was later implemented in the Muslim Family Laws Ordinance of 1961. While 
women gained some rights with regards to marriage, custody of children, divorce, and registration of marriages, the ordinance also set up an arbitration council that brought many areas related to women's lives (such as women's claims to maintenance) under state jurisdiction. Since then, family laws have continued to be a space for contestation between the state and ulama, with the state often acquiescing to the ulama's demands at the expense of women.

While this chapter focuses on the early decades immediately postindependence (1947-67), I will conclude by hinting at some of the ways in which notions of ideal woman/girlhood shifted in the succeeding decades before moving on to the contemporary period in the next chapter. General Ayub's regime ended with the rise of Zulfiqar Ali Bhutto (1972-77), whose socialist message resonated with low-income as well as educated middle-class Pakistanis. Bhutto was ousted by army General Zia ul-Haq in 1977, who ruled for ten years. During his tenure, the little space that women had gained in Pakistan was radically reduced, as he codified a conservative interpretation of Islam into law. Specifically, with the 1979 Iranian Revolution and Soviet encroachment in Afghanistan, Pakistan emerged as a front-line state for the fight against communism as well as Shia theocracy. The United States sought Islam as a bulwark against communism, and Zia aligned with the Wahhabi version of Islam proposed by Jamaat-e-Islami and Saudi Arabia to advance his otherwise illegitimate rule. Zia also intensified the decimation of left-leaning groups and movements. ${ }^{86}$ Zia's Islamization policies reformed all domains of life through changes in laws, school curricula, imposition of dress codes, and a focus on piety in public and personal lives. The ideal woman of Zia's time was the caretaker of the home, who conformed to strict performances of public piety. Her dependency on the family and state was accomplished through various measures that institutionalized her secondary position in society. This included laws such as the Hudood Ordinance (which conflated rape with adultery), the Qisas and Diyat Ordinance (which privatized the crime of honor killings), and the Law of Evidence (which reduced women's testimony to half of that of men). ${ }^{87}$ Women's organizations such as the Women's Action Forum, established in 1981, protested against such laws only to be violently suppressed. A domestically confined, sexually pure, and pious womanhood was codified as the ideal. The result has been a tightening of circuits of surveillance through legal measures. ${ }^{88}$

Zia's policies have had a lasting influence of pathologizing women's autonomy and placing them squarely within the domain of the Muslim home. The Hudood laws were not repealed until 2006, with the Women's Protection Bill; this bill, however, was declared as contrary to Islamic injunctions by the Federal Shariat Court in 2010. Qisas and Diyat laws are still in place. In addition, the dissipation of leftist movements during Zia's regime left much of the feminist agenda to be picked up by transnational organizations such as UN Women and international nongovernmental organizations, as the next chapter will show. Women's agendas advanced by 
such interests, however, have not only clashed with local sensibilities, due to different imaginations about ideal womanhood, but have also been critiqued for often being closely tied to promarket, neoliberal agendas, exacerbating women's exploitation. Yet they form the discursive context within which contemporary meanings of girlhood and womanhood are being shaped. 